\title{
Antisemitism: National or Transnational Constellation?
}

\begin{abstract}
The fundamentals of contemporary antisemitism are explored in this paper through the use of quantitative data sources and techniques. We review the basic content of subject matter; main sources and methods of data analysis; antisemitism definitions and typologies; world population distributions of Jews and antisemites; the position of antisemitism within the complex of Jewish identification; actual Jewish perceptions and experiences of antisemitism; ideological matrices of antisemitism and inner-outer perceptional consistency; responses to antisemitism; and some implications for future research. Data illustrative of these challenges and dilemmas are presented from recent research mostly in the European Union but also the United States and Latin America-emphasizing cognitive, behavioral, and affective aspects.
\end{abstract}

\section{Introduction}

Antisemitism involves some kind of interaction between Jews-who always have constituted a tiny minority of humankind-and the non-Jewish majority. There is no symmetry in such a bilateral relationship. The study and assessment of antisemitic theories, sentiments, and actions stand at the center of a very large body of scientific research, ${ }^{1}$ polemic and advocacy pamphlets, ${ }^{2}$ and infinite pub-

1 Cf. T. W. Adorno et al., The Authoritarian Personality (New York: Harper, 1950); S. Almog, ed., Antisemitism through the Ages (Oxford: Pergamon, 1988); Y. Bauer, ed., Present-Day Antisemitism (Jerusalem: The Vidal Sassoon International Center for the Study of Antisemitism at the Hebrew University, 1988); idem, Rethinking the Holocaust (New Haven: Yale University Press, 2002); E. Ben-Rafael, Confronting Allosemitism in Europe: The Case of Belgian Jews (Leiden: Brill, 2014); M. Brown, ed., Approaches to Antisemitism: Context and Curriculum (New York: The American Jewish Committee and the International Center for University Teaching of Jewish Civilization, 1994); S. Ettinger, Modern Anti-Semitism (Tel Aviv: Moreshet, 1978 [in Hebrew]); C. Y. Glock and R. Stark, Christian Beliefs and Anti-Semitism (New York: Harper Torchbooks, 1966); B. Lewis, Semites and Anti-Semites (New York: Norton, 1987); K. L. Marcus, The Definition of Anti-Semitism (New York: Oxford University Press, 2015); L. Poliakov, The History of AntiSemitism, 4 vols. (Philadelphia: Philadelphia University Press, 2003); M. Wieviorka, L'antisémitisme (Paris: Balland, 2005); R. S. Wistrich, A Lethal Obsession: Anti-Semitism from Antiquity to the Global Jihad (New York: Random House, 2010).

2 Jewish Voice for Peace, On Antisemitism: Solidarity and the Struggle for Justice, with a preface by J. Butler (Chicago: Haymarket Books, 2017); UN Watch, The United Nations and Antisemitism: 2008-2017 Report Card (New York: UN Watch, 2018).

๑ OpenAccess. (C) 2022 Sergio DellaPergola, published by De Gruyter. (cc))BY-NC-ND This work is licensed under the Creative Commons Attribution-NonCommercial-NoDerivatives 4.0 International License. https://doi.org/10.1515/9783110671971-003 
licist writings. ${ }^{3}$ Nonetheless, antisemitism still offers ample space for new research, new questions, and new answers. In this respect, the following excerpt is of interest:

You know what a big crowd it is, how they stick together. How influential they are in informal assemblies... It was customary to send gold to Jerusalem... The senate... forbade the export of gold, but to resist this barbaric superstition was an act of firmness to defy the crowd of Jews... for the welfare of the state...

No, this is not an attack against one George Soros or one Benjamin Netanyahu and their crowd; this is Cicero in his speech Pro Flacco delivered in Rome in the year 59 B.C.E. ${ }^{4}$ Many today would probably recognize as part of antisemitic speech captions such as what a big crowd, how they stick together, how influential they are, barbaric superstition, but also send gold to Jerusalem and for the welfare of the state. Considering the significantly foreign-policy context of his harangue, we do not contend here that Cicero was an antisemite, but it is remarkable how resilient and repetitive some of the light motifs of anti-Jewish critique can be across long-term cultural and political history.

Antisemitism indeed is a timeless and transnational feature that often informs parts of discourse by the hegemonic majority or by influential groups within it toward "them, the other"-in this case a particular minority essentially designated as illegitimate. Interestingly, the minority too appears to hold some entrenched modes of thought regarding "them, the other"-in this case the hegemonic majority:

Their idols are silver and gold, the work of men's hands. They have mouths, but they speak not; eyes have they, but they see not. They have ears, but they hear not; noses have they, but they smell not. As for their hands, they touch not; as for their feet, they walk not; they give no sound through their throat. They that make them shall be like unto them; yea, every one that trusteth in them. ${ }^{5}$

To even more colorfully express the sense of diffidence that has existed and still persists between Jews and non-Jews, I may quote the old Tuscan saying:

Con le budella del buono strangolerei il cattivo.

3 Cf. e.g. S. Beller, Antisemitism. A Very Short Introduction (New York: Oxford University Press, 2015).

4 Cicero, Pro Flacco, 28:66, cited in M. Stern, Greek and Latin Authors on Jews and Judaism, vol. 1 (Jerusalem: The Israel Academy of Sciences and Humanities, 1976), 197.

5 Psalm 135:15-18, quoted in S. Singer, ed., The Authorised Daily Prayer Book of the Hebrew Congregations of the British Empire (London: Eyre and Spottiswood, 2012). Our italics. 
(With the guts of the good guy I would strangle the bad guy.)

Many antisemites, but many Jews as well, would subscribe to this caption when referring to the opposite side.

One sure implication for research about antisemitic prejudice, stereotypes, negative paradigms, or aggression is that such features need to be examined and investigated from both ends of the perpetrator-victim dyad. Such interaction usually involves the cognitive, the behavioral, and the affective domains of those many people who in their life have had experiences that can be categorized as antisemitic, or at least hold perceptions of what antisemitism is or might be.

In this paper we present selected results on perceptions and experiences of antisemitism by Jews-typically the victim side. The materials presented here derive from a wide range of sources developed in recent years in different countries and aim to contribute by clarifying certain aspects of the content of subject matter that are still in need of elucidation, as well as stimulating more cogent planning of future research in the area of antisemitism studies. An emphasis here on quantitative analytic tools is not meant to demonstrate superiority of a given methodology over another. It rather aims at showing the value added that those tools can contribute unveiling scarcely discussed aspects related to cognitive, behavioral, and affective aspects of the Jewish experience with antisemitism and to enrich multidisciplinary discourse in the field.

\section{Contents of Subject Matter}

When antisemitism turns into a topic for research, in particular one that applies quantitative tools, what are its essential referential axes? A huge and valuable research effort has been devoted over time to the issue, but still contemporary research may benefit from some additional efforts at conceptualization and systematization. ${ }^{6}$ The first imperative step is identifying something that can be measured, be it an event or a perception of an experience or of a trend that links together several events. These eventual measurement units can be of very different nature, ranging from the physical annihilation of self as a victim to impressionistic perceptions of something that might or might not have happened. They can involve cognitive, behavioral, and affective aspects. In current

6 Cf. S. W. Popper et al., "Evaluating Contemporary Antisemitism: A Framework for Collaborative Conceptualization, Measurement and Assessment," draft paper, ISGAP, last updated January 22, 2017, https://isgap.org/wp-content/uploads/2019/10/Measuring-Antisemitism.pdf. 
practice, several of these options have been explored quite in depth but several others have not.

Looking at past research on antisemitism, we can detect studies of antisemitic notions, acts, experiences, perceptions, discourse, and emotions. But these alternative paths have not been pursued each to the same and satisfactory depth and extent. One clarification must come since the outset: there may be a wide gap between actual experiences of antisemitism and perceptions of existing antisemitism. The subjective can be disjoint from the objective through the mediation of personal and environmental characteristics, not the least of which is the degree of Jewish identification of those who report manifestations of antisemitism. ${ }^{7}$ Ideally, any comparisons should be drawn with the same and appropriate measuring and definitional standard.

Fundamental axes of research on antisemitism should-but do not alwaysinclude a minimum core of essential contents:

- The nature and frequency of antisemitic events

- The conceptual contents of offence

- The place of antisemitism as a component of Jewish identity

- The ideological background of perpetrators

- The geographical, demographic, and socioeconomic correlates of offenders and the offended

- The depth of damage caused by offence

- The emotional reaction by the offended

- The transmission channels of offence

- The cumulated influence (total number of persons exposed to) offence

- The Jewish response to offence

- The general response and efficiency of sanction applied

To orderly and systematically study the character and incidence of antisemitism one should first note the type of antisemitic event. Antisemitism is a matter of expressions of ideas, concepts and stereotypes, diffusion of negative prejudices, hostile behavior, and physical aggression against inanimate objects, discrimination against individuals and communities, actions against specific persons ranging between harassment, physical violence, to the extreme of murder.

Frequency and impact of antisemitism should consider the number of events, number of perpetrators, and number of victims. We need to carefully assess the number of persons exposed to a given event. In one of the most vicious websites

7 Cf. U. Rebhun, "Correlates of Experiences and Perceptions of anti-Semitism among Jews in the United States,” Social Science Research 47 (2014): 44-60. 
I visited, I was the first visitor: the site was highly offensive, but its public impact was close to nil. Such assessment of the multiplier of events and people exposed to them is prominently lacking in the literature.

We need a comparative framework that considers a short- and long-term timeline and is capable of separating the underlying antisemitism from the impact of any association with external events. It is sometimes assumed that antisemitic perceptions and actions cyclically co-variate with the economic conjuncture and business cycle, ${ }^{8}$ particularly at times of deeper economic recession, or with periodical outbursts of violence between the State of Israel and the Palestinians. Such assumptions call for empirical validation. We also need to analyze and understand the selective incidence of antisemitism according to the geographic, demographic, and socio-cultural characteristics of all those involved: perpetrators, victims, and spectators. There may be a subtle division of labor between the conceptualization and leadership capabilities of intellectual and political elites, and the perceptions and sensitivities by less educated or lower class people-or by the people at large.

The whole gamut of human experiences can be organized into three main categories: cognitive/intellectual, behavioral/instrumental, and affective/emotional. Insert 1 delineates graphically the expected space partition in a multivariate analysis aimed at better understanding antisemitic perceptions and experiences. Such partition relies on an assumption that appropriate variables were actually included in a given study so that they can spread covering each of the three mentioned human experience dimensions.

In general, most historical research about antisemitism stresses either a cognitive or a behavioral/instrumental dimension. It is perhaps surprising how much the affective/emotional aspect has usually been neglected. For example, does antisemitism generate among Jews anxiety, anger, fear, aggressiveness, passivity, activism, loneliness, solidarity, creativity, or other feelings? Does it strengthen or weaken previously held Jewish religious or ethnic identities? Does it strengthen or weaken empathy, solidarity, and national identification with the country of residence of affected Jews?

Each of the mentioned contexts requires different analytic tools and probably also different theoretical frameworks. It is therefore necessary to carefully specify the types of sources, research methods, and technical assumptions adopted in any given analysis of the empirical evidence.

8 Cf. S. Epstein, Cyclical Patterns in Antisemitism: The Dynamics of anti-Jewish Violence in Western Countries since the 1950s (Jerusalem: Vidal Sassoon International Center for the Study of Antisemitism at the Hebrew University, 1993). 


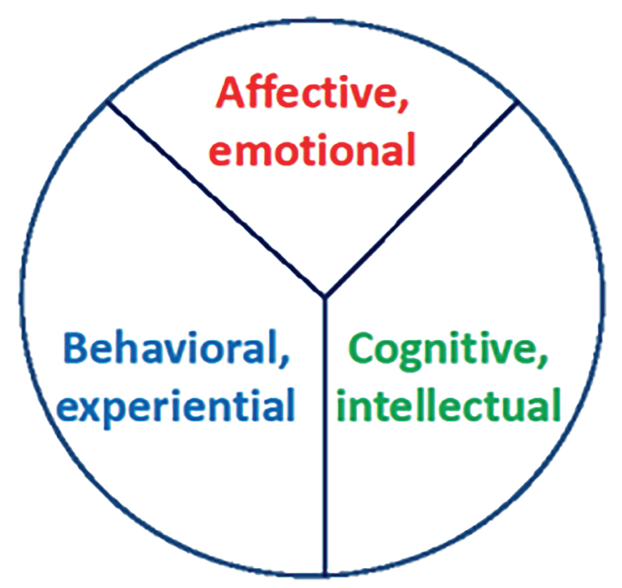

Image 1: Expected Structure of Contents of Antisemitism as Part of Human Experience Domains.

\section{Sources of Data and Methods of Analysis}

An important issue for clarification is the sources of data available and the main investigation methodologies pursued. Insert 2 presents selected examples of the logical sequence followed in actual practice in planning some of the main recent research instruments about antisemitism.

Much attention has been devoted to the growth of several inventories of events rated as antisemitic. These databases are developed by Jewish organizations both community and academic oriented, as well as by general public organizations. ${ }^{9}$ We also recognize studies of perceptions of antisemitism, by Jews, ${ }^{10}$ and/or by others; ${ }^{11}$ studies of violence or harassment against the self

9 Cf. OSCE/ODIHR, Hate Crime Reporting. Anti-Semitism 2016 (Vienna: OSCE/ODIHR, 2016), http://hatecrime.osce.org/what-hate-crime/anti-semitism; Kantor Center for the Study of Contemporary European Jewry, ed., Antisemitism Worldwide 2017: General Analysis Draft (Tel Aviv: Moshe Kantor Database for the Study of Contemporary Antisemitism and Racism, 2018).

10 Cf. FRA - European Union Agency for Fundamental Rights, Discrimination and Hate Crime against Jews in EU Member States: Experiences and Perceptions of Antisemitism (Luxembourg: Publications Office of the European Union, 2014), http://fra.europa.eu/sites/default/files/fra2013-discrimination-hate-crime-against-jews-eu-member-states-0_en.pdf; idem, Experiences and Perceptions of Antisemitism: Second Survey on Discrimination and Hate Crime against Jews in the EU (Luxembourg: Publications Office of the European Union, 2018), https://fra.europa.eu/sites/ default/files/fra_uploads/fra-2018-experiences-and-perceptions-of-antisemitism-survey_en.pdf; 


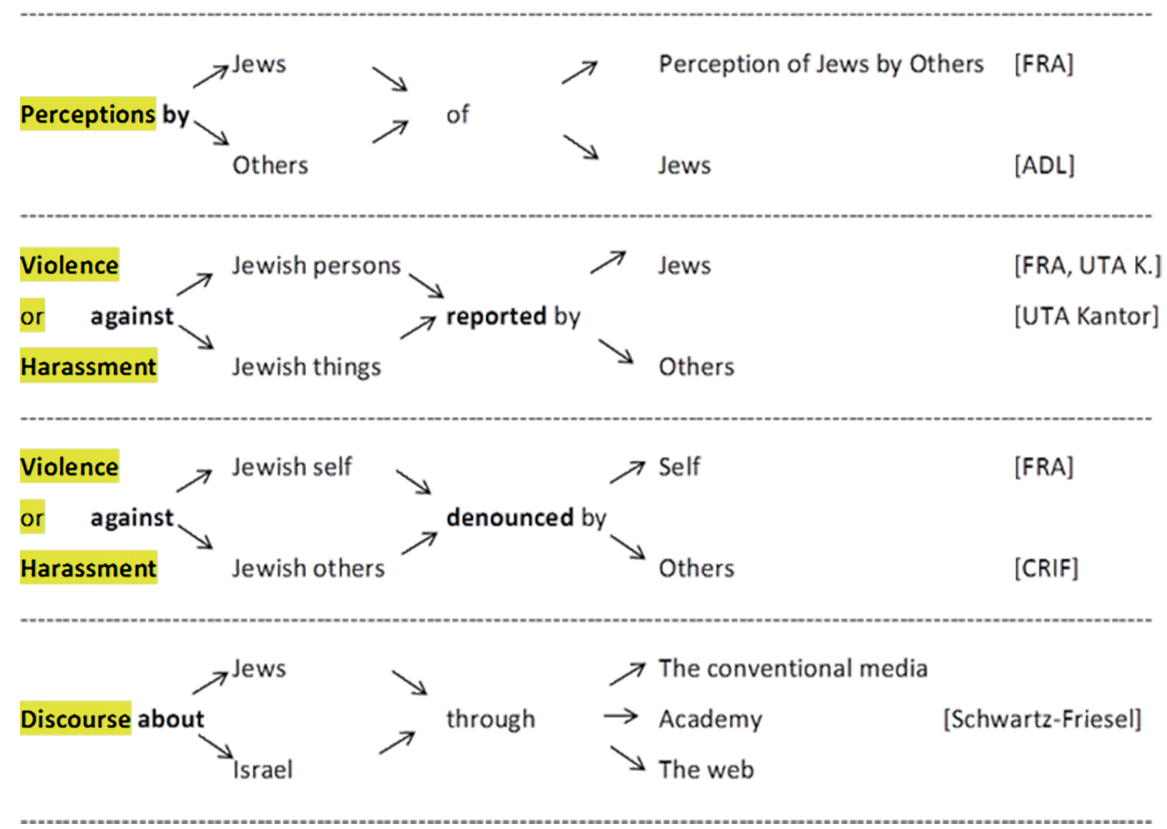

Image 2: Main Research Strategies in the Study of Antisemitism.

as a Jew, or against other Jewish persons, or against Jewish things, reported or denounced by Jews and/or by others; ${ }^{12}$ and studies of the contents of discourse, mostly about Jews or about Israel, through different possible channels of diffu-

idem, Antisemitism: Overview of Data Available in the European Union 2008-2018 (Luxembourg: Publications Office of the European Union, 2019), https://fra.europa.eu/sites/default/files/fra_ uploads/fra-2019-antisemitism-overview-2008-2018_en.pdf; idem, Young Jewish Europeans: Perceptions and Experiences of Antisemitism (Luxembourg: Publications Office of the European Union, 2019), https://fra.europa.eu/sites/default/files/fra_uploads/fra-2019-young-jewish-euro peans_en.pdf; idem, Antisemitism: Overview of Antisemitic Incidents Recorded in the European Union 2009-2019 (Luxembourg: Publications Office of the European Union, 2020), https:// fra.europa.eu/sites/default/files/fra_uploads/fra-2020-antisemitism-overview-2009-2019_en.pdf. 11 Cf. “ADL Global 100: An Index of Anti-Semitism," Anti-Defamation League, issued 2014, accessed January 19, 2021, https://global100.adl.org/map.

12 Cf. FRA, Discrimination and Hate Crime; M. Knobel, Hä̈ne et violences antisémites: Une rétrospective 2000-2013 (Paris: Berg International, 2013); OSCE/ODIHR, Hate Crime Reporting; Kantor Center, Antisemitism Worldwide. 
sion such as large bulks of electronic mails, internet sites, Facebook networks, and the like. ${ }^{13}$

Cross-sectional surveys of populations at selected points of time have tried to measure the incidence of prejudice as perceived within the Jewish and general public. In 2012 the FRA (the European Union's Fundamental Rights Agency) initiated a study of Jewish perceptions of antisemitism among Jews in nine EU countries. ${ }^{14}$ In one of these countries, Romania, the quality of data was insufficient, and the country was dropped from further analyses. Countries were selected for the study primarily because of their larger Jewish population size but also in view of their locations in the different regions of the continent: north, south, east, and west. About 6,000 Jews responded via the web. To assess validity of the samples, comparisons were performed with background demographic data independently available for some countries. The UK had good census data; Germany and Italy had good Jewish community registers. France did not have either but could rely on several independent national Jewish population surveys. Hungary and Sweden too could display relatively recent Jewish survey data, while Latvia and Romania had at least minimal evidence from national population censuses. Belgium is the weakest case having none of the above. In the FRA findings, the basic demographic profiles of those surveyed broadly corresponded with those known from other independent sources, which added reliability to the sample. The study, in addition to detailed evidence about Jewish perceptions and experiences with antisemitism, collected data on the sociodemographic and Jewish identification profile of respondents.

In a different study, ADL (The Anti-Defamation League) approached 500 individuals in each of 102 countries, for a total of over 50,000 respondents. ${ }^{15}$ Respondents were asked to express agreement or disagreement facing a list of anti-Jewish prejudices (see below). Those who agreed with 6 or more statements were included in an index of antisemitism. There may be doubts about the reliability of such a measuring procedure, but this is not to minimize the usefulness of the ADL study, which for the first time provided some measure of the extent of antisemitism in 102 countries. The study unveiled less antisemitism in North America than in Latin America, in Western than in Eastern Europe. In Southeast Asia-such as in South Korea, Japan, and China-where societies were not exposed to Christian thought, classic antisemitism was found to be quite low. Antisemitism was found to be highest in Muslim countries.

13 Cf. M. Schwarz-Friesel and J. Reinharz, Inside the Antisemitic Mind: The Language of JewHatred in Contemporary Germany (Boston: University Press of New England, 2017).

14 Cf. FRA, Discrimination and Hate Crime.

15 Cf. "ADL Global 100: An Index of Anti-Semitism." 
Besides sources directly focused on antisemitism, several other studies provide essential information on the interaction between antisemitism and other aspects of Jewish population and society. Here we take advantage of two such studies:

- $\quad$ The 2013 Pew survey of Jewish Americans included 2,786 Jews by religion, 689 Jews of no religion, and 1,190 people of Jewish background and covered a wide range of topics concerning Jewish identification in the United States. ${ }^{16}$ Only Jews who do not have another religion were included in the present study.

- The 2013 Transnational Latin American Jewish Educator study explored the professional experiences and identification of 1,379 educators in formal and informal Jewish educators-primarily residing in Mexico and Argentina but also migrated to many other countries out of the continent including Israel. ${ }^{17}$

Outside sociodemographic surveys, there exists much less ongoing analysis of openly or latently antisemitic verbal and textual content expressed in the conventional printed and electronic media, on the web and in the fast developing social media. Carefully selected semantic associations between words can result in much more powerful and disruptive effects than mere acts of violence. The problem is that the latter are easy to detect and report, while the former require careful coding and wide command of historical, philosophical, and literary sources. What also has been prominently missing is studies incorporating a systematic time perspective and broad sets of external social indicators that would provide the necessary context to the specific attitudinal and behavioral patterns being investigated. For sure, further mapping needs to be developed in order to ascertain whether the actual contents of antisemitism reflect a permanent manifest and/or latent structure of contents, replicable under different circumstances, or rather reflect contingent situations related to specific times and places.

Regarding the method of data analysis, inasmuch as the focus is on quantitative analysis, the dominant mode in the literature is simple tabulations of data.

16 Cf. "A Portrait of Jewish Americans: Findings from a Pew Research Center Survey of U.S. Jews,” Pew Research Center, issued October 1, 2013, accessed January 19, 2021, https://www. pewforum.org/2013/10/01/jewish-american-beliefs-attitudes-culture-survey/.

17 Cf. J. Bokser Liwerant et al., El educador judío latinoamericano en un mundo transnacional, vol. 1. Informe de investigación; vol. 2. Síntesis, conclusiones y recomendaciones del informe de investigación (Jerusalem: The Hebrew University, Centro Liwerant para el estudio de America Latina, España, Portugal y suyas Comunidaded Judías; Mexico: Universidad Hebraica; Buenos Aires: AMIA, 2015). 
Description of features does not usually generate more complex reference to theories or processes that require the simultaneous processing of vastly larger quantities of information. In this respect the main mode of thought is causal inference, in which a given variable is posited as the one to be explained the dependent variable), and one or more explanatory variables are posited in order to verify the respective fitness and explanatory power within the hypothesized model. ${ }^{18}$ Some examples of this approach will be provided below.

A different approach is represented by Similarity Structure Analysis (SSA) - a methodology aimed at exploring the interrelations that exist among large numbers of variables rather than focusing on explaining only one at a time. ${ }^{19}$ SSA, exemplified in the following, is based on the correlation coefficients that link together all of the variables included in a given analysis, and transforms the extent of co-variation of those variables-namely their proximity or contrapositioninto maps. The emerging visual configurations are helpful at assessing the overall contents of subject matter and its logical partitions.

\section{Definitions and Typologies of Antisemitism}

One unescapable question is what is antisemitism? and how do we recognize it? It is not easy to reach consensus in this respect, partly because of the great complexity of the issue at stake, partly also because antisemitism has become a bone of contention in a political arena marred by current issues one of which is the struggle against a State of Israel that besides being a sovereign political entity, also constitutes a sensitive pole of reference in the personal identity of many Jews. In an attempt to create a consensual international point of reference, on May 26, 2016, the Plenary of IHRA (International Holocaust Remembrance Alliance) in Bucharest decided to adopt the following non-legally binding working definition of antisemitism:

Antisemitism is a certain perception of Jews, which may be expressed as hatred toward Jews. Rhetorical and physical manifestations of antisemitism are directed toward Jewish

18 Cf. U. Rebhun, "Correlates of Experiences.”

19 Cf. L. Guttman, "A General Nonmetric Technique for Finding the Smallest Coordinate Space for a Configuration of Points," Psychometrika 33 (1968): 469-506; R. Amar and S. Levy, "SSASimilarity Structure Analysis," in Encyclopedia of Quality of Life and Wellbeing Research, ed. A. C. Michalos (Dordrecht: Springer, 2014), 6306-313. 
or non-Jewish individuals and/or their property, toward Jewish community institutions and religious facilities. ${ }^{20}$

Probably better than this rather tepid prose, the remainder of the document clarifies that:

antisemitic acts are criminal when they are so defined by law (for example, denial of the Holocaust or distribution of antisemitic materials in some countries). Criminal acts are antisemitic when the targets of attacks, whether they are people or property-such as buildings, schools, places of worship and cemeteries-are selected because they are, or are perceived to be, Jewish or linked to Jews. Antisemitic discrimination is the denial to Jews of opportunities or services available to others and is illegal in many countries. ${ }^{21}$

In addition, eleven modes of harassment, aggression, delegitimation, and other forms of behavior aimed against Jews as individuals or a collective were specified.

Two items addressed too much Jewish power concepts:

- Making mendacious, dehumanizing, demonizing, or stereotypical allegations about Jews as such or the power of Jews as collective-such as, especially but not exclusively, the myth about a world Jewish conspiracy or of Jews controlling the media, economy, government or other societal institutions.

- Accusing Jews as a people of being responsible for real or imagined wrongdoing committed by a single Jewish person or group, or even for acts committed by non-Jews.

Two items addressed Holocaust denial or minimization concepts:

- Denying the fact, scope, mechanisms (e. g. gas chambers) or intentionality of the genocide of the Jewish people at the hands of National Socialist Germany and its supporters and accomplices during World War II (the Holocaust).

- Accusing the Jews as a people, or Israel as a state, of inventing or exaggerating the Holocaust.

Six items addressed delegitimation of Israel concepts:

- Accusing Jewish citizens of being more loyal to Israel, or to the alleged priorities of Jews worldwide, than to the interests of their own nations.

20 "Working Definition of Antisemitism," International Holocaust Remembrance Alliance, issued May 26, 2016, accessed January 8, 2021, https://www.holocaustremembrance.com/sites/ default/files/press_release_document_antisemitism.pdf.

21 Ibid. 
- Denying the Jewish people their right to self-determination, e. g., by claiming that the existence of a State of Israel is a racist endeavor.

- Applying double standards by requiring of it a behavior not expected or demanded of any other democratic nation.

- Using the symbols and images associated with classic antisemitism (e.g., claims of Jews killing Jesus or blood libel) to characterize Israel or Israelis.

- Drawing comparisons of contemporary Israeli policy to that of the Nazis.

- Holding Jews collectively responsible for actions of the state of Israel.

One item directly addressed destroying the Jews concepts:

- Calling for, aiding, or justifying the killing or harming of Jews in the name of a radical ideology or an extremist view of religion.

Against the IHRA official document, it is interesting to note that different research efforts that preceded it chronologically delineate further typologies for a standard definition of antisemitism, which do not greatly deviate from the IHRA suggestions. As mentioned, different sources can provide images of varying levels of intensity of the antisemitic phenomenology, but what is more interesting is the amount of coherence between these different sources. Comparisons can be performed with the FRA 2012 survey of Jewish perceptions of antisemitism in nine EU countries $^{22}$ and the ADL between 2013 and 2014, and $2015^{23}$ studies of antisemitic perceptions among the total populations in over hundred countries. In the 2012 FRA questionnaire, eight frequently heard hostile statements made by non-Jewish people were suggested for evaluation by Jewish respondents. Of these:

Two items addressed too much Jewish power concepts:

- Jews have too much power in country in economy, politics, media

- Jews are responsible for the current economic crisis

Two items addressed Jewish foreignness concepts:

- The interests of Jews in Country are very different from the interests of the rest of the population

- Jews are not capable of integrating into Country's society

Two items addressed Holocaust denial or minimization concepts:

- Jews exploit Holocaust victimhood for their own purposes

- The Holocaust is a myth or has been exaggerated

22 Cf. FRA, Discrimination and Hate Crime.

23 Cf. "ADL Global 100: An Index of Anti-Semitism." 
Two items addressed Israel delegitimation concepts:

- Israelis behave "like Nazis" towards the Palestinians

- Jews are only a religious group and not a nation

The ADL 2013-2014 and 2015 surveys were less balanced in terms of anti-Jewish perceptional contents. In a sense it wasted some of the effort by asking somewhat repetitive questions. The following eleven questions suggesting anti-Jewish prejudices were asked:

Six items addressed too much Jewish power concepts:

- Jews have too much power in the business world.

- Jews have too much power in international financial markets.

- Jews have too much control over global affairs.

- Jews have too much control over the United States government.

- Jews have too much control over the global media.

- Jews are responsible for most of the world's wars.

Three items addressed Jewish foreignness concepts:

- Jews don't care about what happens to anyone but their own kind.

- People hate Jews because of the way Jews behave.

- Jews think they are better than other people.

One item addressed Holocaust denial or minimization concepts:

- Jews still talk too much about what happened to them in the Holocaust.

One item addressed both Israel delegitimation and foreignness concepts:

- Jews are more loyal to Israel than to [this country/the countries they live in].

In the data analysis, antisemitism was operationally defined as the percentage of individuals who in a country responded probably true to at least six out of the eleven items.

In spite of the different emphases in these different lists of items, we should note that they all pertain to the cognitive domain, that is, they refer to definitions of a given situation that is posited a priori to deviate from a normative paradigm of what an exemplary Jew or exemplary Jewish community is supposed to be. Behavioral or affective aspects were not actually included in these indicators of antisemitism. Significant overlap exists across the three different typologies proposed above regarding certain main themes of interest or conceptual components of the complex of antisemitic expressions: (1) old style delegitimation of the Jew as an individual and as a community; (2) delegitimation of the Shoah (also designated as the Holocaust); and (3) delegitimation of the State of Israel. 
These various components appear above just as serially listed and will be addressed here below from the angle of empirical observation in a more comprehensive and interactive mode. Clearly, antisemitic expressions aim at creating damage or at least offence against the stigmatized minority, as well as a sense of superiority and dominance in the mind of the offender, while seeking consensus and support among the broader public. The question of the cumulated influence of the various components of antisemitic offence remains open.

\section{Population Distributions: Jews and Antisemites}

The next question is how expressions of antisemitism come to relate to real persons, namely the Jews in a given population. To answer the question, we review where the Jews are and where the antisemites are, and whether there is a meaningful correlation between the two population distributions. In the course of the last several decades-particularly since the end of World War II but also, following the June 1967 Six Day War, since the 1970s-Jewish population distribution worldwide has undergone dramatic changes. The main changes were prompted by massive international migration flows and to some extent by differential rates of Jewish natural increase or decrease reflecting marriage, birth and death, and assimilation patterns in different countries. ${ }^{24}$ Overall, the Jewish population grew very rapidly in Israel, and to a lesser extent in North America, Australia, and some Western European countries, while strong declines were recorded in North Africa, the Middle East, and Eastern Europe, and to a lesser extent in Latin America and South Africa. The question of how changes in Jewish population distribution can be related to the varying spread of antisemitism is relevant in view of the fact that transformations of Jewish geography and of other social indicators are not just a matter of territorial distribution but also significantly affect exposure of Jews to different political, cultural, and socioeconomic environments.

A cultural-political typology of world countries based on modernization studies and on the World Value Survey, ${ }^{25}$ produced a partition into eight geocultural or civilization areas, including English-speaking countries beyond the Atlantic Ocean (the US, Canada, Australia, New Zealand), European countries subdivided between Catholic and Protestant nations, Latin America, countries

24 Cf. S. DellaPergola and U. O. Schmelz, "Demography,” in Encyclopedia Judaica (Farmington Hills: Thompson Gale, 2006), 5:553-72.

25 Cf. R. Inglehart and C. Welzel, Modernization, Cultural Change and Democracy: The Human Development Sequence (Cambridge: Cambridge University Press, 2005). 
formerly under the hegemony of the Soviet Union, countries in Sub-Sahara Africa, Muslim countries, and Confucian-oriented Asian countries. In the case of Jews, it was appropriate to add a ninth category represented by the State of Israel and its close environment of the Palestinian Territories, with an eye not so much to internationally recognized legal definitions of boundaries but rather to the actual social environment perceived by people on the ground. Insert 3 presents a distribution of the world's total and Jewish populations in absolute numbers and percentwise, and the percent of Jews within the total population of each area as of 2013. The Jewish and total population spreads were totally different, with $44.9 \%$ of the Jews living in English-speaking countries versus $6.3 \%$ of total world population, and another $43.4 \%$ living in Israel versus $0.2 \%$ of total population, while at the other end $46.9 \%$ of total population lived in Confucian Asian countries versus $0.1 \%$ of Jews, and another $15.3 \%$ lived in Muslim countries versus $0.2 \%$ of Jews. ${ }^{26}$ What is no less significant is the density of Jewish population across these different cultural areas, ranging from 14 Jews per 1,000 inhabitants in English speaking countries down to 2.6 and 1.4 per 1,000 in Catholic and Protestant European countries, 0.9 and 0.6 per 1,000 in excommunist and Latin American countries, and less than 0.1 per 1,000 in the most populated areas of the world: Sub-Sahara Africa, Muslim countries, and Asian Confucian countries. In other words, exposure of the general population to a Jewish presence is dramatically different across countries and cultural areas. Only in Israel-also including in these calculations the Palestinian population of the West Bank and Gaza-does the Jewish population constitute a majority, albeit a contained one, of 505 per 1,000 inhabitants. In the State of Israel itself, Jews constitute $75 \%$ of the total.

Jewish population distribution worldwide indicates that socio-economic development-measured here through the United Nations Human Development Index $\mathrm{HDI}^{27}$-and Jewish population density ${ }^{28}$ - stand in strong and direct relationship. Insert 4 shows that country development accounts for $44 \%$ of total variation in Jewish population distribution, which in the social sciences is considered a very powerful directional relationship. More socioeconomic

26 Cf. S. DellaPergola, “World Jewish Population 2013,” in American Jewish Year Book 113, ed. A. Dashefsky and I. Sheskin (Dordrecht: Springer, 2013), 278-358.

27 Cf. UNDP, Human Development Report 2017 (New York: United Nations Development Programme, 2017).

28 Cf. S. DellaPergola, “World Jewish Population 2017,” in American Jewish Year Book 117, ed. A. Dashefsky and I. Sheskin (Dordrecht: Springer, 2017), 297-377. 


\begin{tabular}{l|rrrrrr}
\hline Civilization area & $\begin{array}{c}\text { Jewish } \\
\text { population }\end{array}$ & $\begin{array}{c}\text { Total } \\
\text { population }\end{array}$ & Jews \% & Total \% & $\begin{array}{c}\text { Jews } \\
\text { per } \mathbf{1 0 0 0}\end{array}$ \\
\hline Total world & $13,854,800$ & $7,056,691,800$ & 100.0 & 100.0 & 1.963 \\
\hline English speaking & $6,216,200$ & $443,248,000$ & 44.9 & 6.3 & 14.04 \\
\hline Israel & $6,014,300$ & $11,909,800$ & 43.4 & 0.2 & 504.99 \\
\hline Catholic Europe & 563,600 & $213,871,000$ & 4.1 & 3.0 & 2.645 \\
\hline Protestant Europe & 189,300 & $132,470,000$ & 1.4 & 1.9 & 1.43 \\
\hline Latin America & 384,900 & $599,003,000$ & 2.8 & 8.5 & 0.64 \\
\hline Ex-Communist & 374,600 & $408,300,000$ & 2.7 & 5.8 & 0.92 \\
\hline Sub-Sahara Africa & 71,300 & $858,900,000$ & 0.5 & 12.2 & 0.08 \\
\hline Muslim & 31,150 & $1,080,100,000$ & 0.2 & 15.3 & 0.03 \\
\hline Confucian Asia & 9,450 & $3,308,890,000$ & 0.1 & 46.9 & 0.00 \\
\hline
\end{tabular}

Image 3: Source of data: DellaPergola, "World Jewish Population 2013," cit. Adjusted by author.

development is conducive to more frequent Jewish presence. ${ }^{29}$ Higher Jewish population concentrations clearly appear in the more developed Englishspeaking (here labeled Anglos) and European countries. The only exceptions are a few developed societies in Asia, which have very tiny Jewish populations. The position of Israel in this chart (which for clarity of display uses a logarithm scale of Jewish population density) is very peculiar, with by far the highest proportion of Jews. It reflects the ideological determinants of Jewish migration to Israel historically. But Israel is also a developed country, ranked $19^{\text {th }}$ out of 200 countries. It may therefore be an attractive destination besides any consideration of religion and culture. Of the whole Jewish diaspora, in 2016, 88\% lived in countries more developed than Israel, and $12 \%$ in countries less developed.

It is also relevant to examine the relationship between the human development of a country and the frequency of antisemitism there (Insert 5). It appears that the more developed a country, the lower the incidence of antisemitic opinions among the population, at least as measured through the ADL study. About $17 \%$ of the country variation in the frequency of antisemitism is explained by the level of HDI, a fairly strong relationship. It can be easily inferred that socioeco-

29 The alternative hypothesis that Jewish presence causes greater development appears untenable in view of the very low percentages of Jews in all countries except Israel. 
Log of Jews per 1000 population

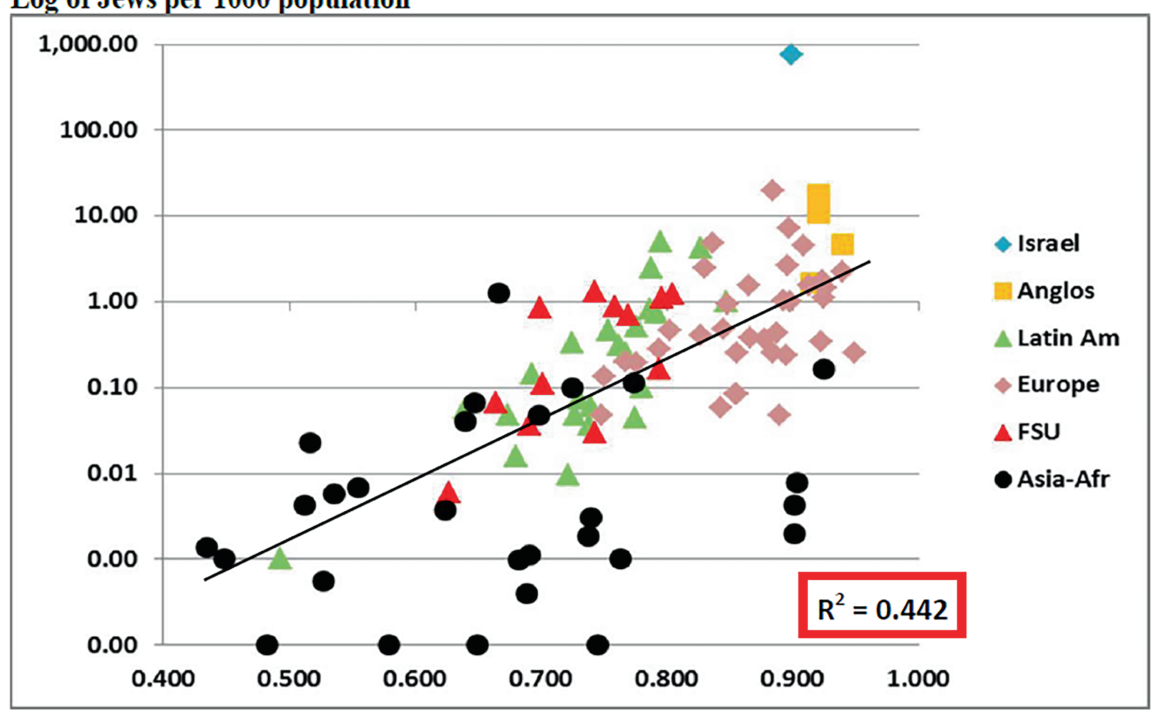

HDI

Image 4: Percent of Jews among Total Population in World Countries by Human Development Index, 2016. Sources: UNDP, Human Development Report, 2017, cit; DellaPergola, "World Jewish Population 2017," cit.

nomic development is correlated with higher levels of democracy, freedom of expression, and autonomous self-regulation of different voluntary groups within the larger society. A more pluralistic nature of democratic regimes and openness to diversity of views and lifestyles among the broader population may be related to less antisemitism.

On the other hand, antisemitism and Jewish population density stand in reverse relationship. Measured percentwise on the basis of the ADL study, the frequency of antisemitism accounts for only $5 \%$ of total variation in the percentage of Jews in the different countries. Less antisemitism is associated with more frequent Jewish presence, but the weakness of the relationship indicates that, unlike in the past, antisemitism today does not have the power to generate great Jewish emigration flows and population redistribution to more congenial locations. But, importantly, the other way around is also true: a more frequent Jewish presence is associated with less antisemitism. This is demonstrated in Insert 6 where the dependent variable is posited to be the ADL Index of antisemitism while the explaining variable is the proportion of Jews in a country. The relationship is evidently negative, although its explanatory power remains quite weak: $7.8 \%$ of explained variance. The finding is nevertheless interesting because it 
ADL 2014 percent of antisemitism

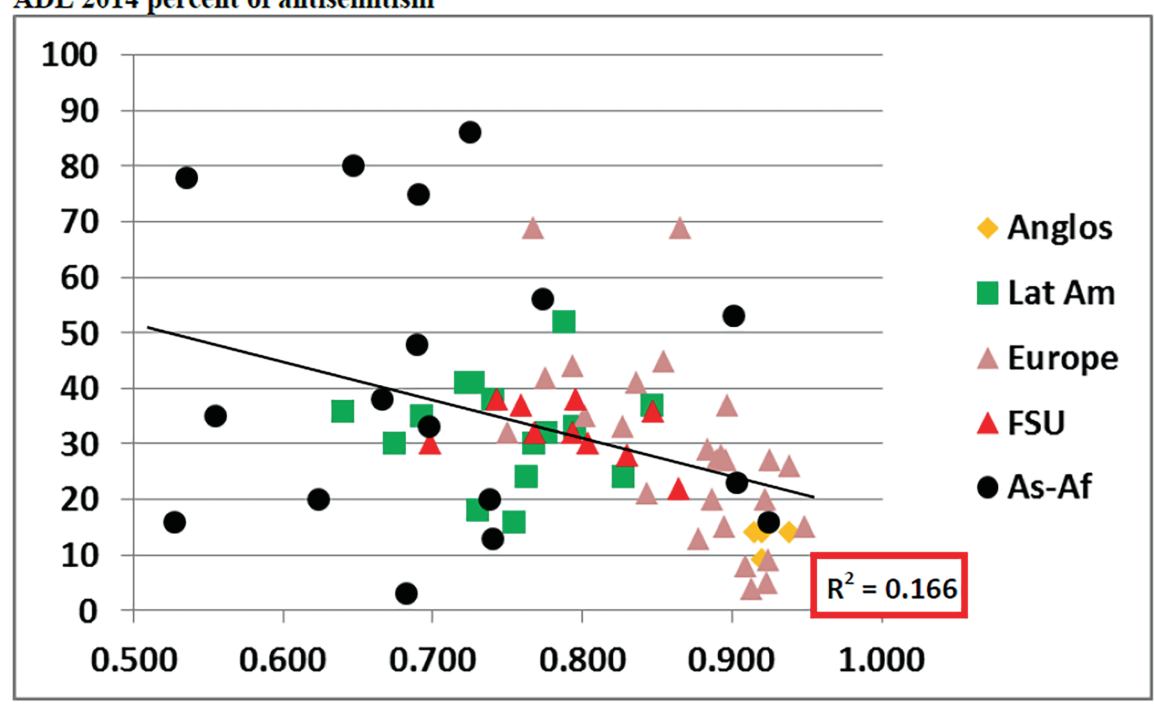

HDI

Image 5: Index of Antisemitism by Human Development Index in World Countries, 2016. Sources: UNDP, Human Development Report, 2017, cit.; Anti Defamation League, ADL Global 100 , cit.

contradicts at least one of the many strands of antisemitism, namely that it is the Jews themselves who bring antisemitism upon their heads because of their alleged misbehaviors.

\section{Antisemitism and Jewish Identification}

Having outlined the reciprocal positions of Jews and antisemitic manifestations in the macrosocial perspective of the global system of countries, it is now important to detect what possible position antisemitism may hold within the collective religious ethnic and cultural identification of Jews. In the study of Jewish society, antisemitism is typically treated as an exogenous variable-something that happens out of the Jewish collective and penetrates into the Jewish collective affecting it to its depth. A complementary and much needed approach calls for assessing the role and weight of antisemitism and the commitment to fight against it as one of the several components of Jewish identification. We discuss this issue with respect to Jewish identification in three different cultural areas: in the eight EU countries investigated in the 2012 FRA survey, in the United States in 
ADL 2014 percent of antisemitism

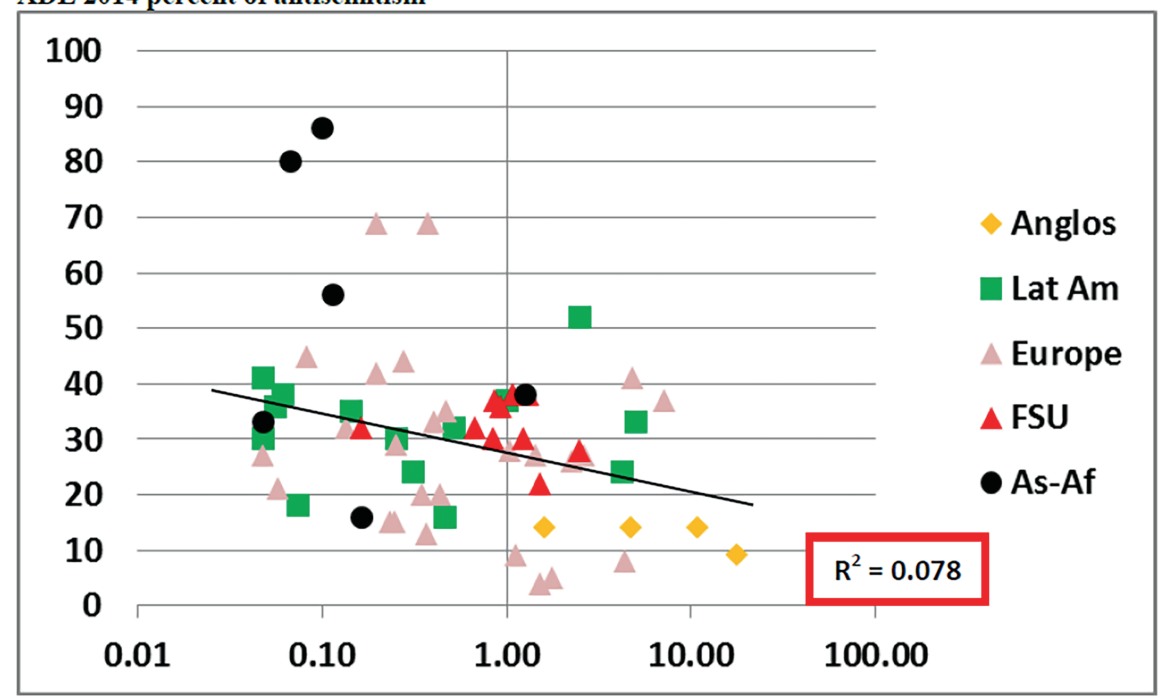

Log of Jews per 1000 population

Image 6: Index of Antisemitism by Percent of Jews among Total Population in World Countries, 2016.

Sources: DellaPergola, “World Jewish Population 2017," cit.; Anti Defamation League, $A D L$ Global 100, cit.

2013, and among a sample of Jewish teachers from different Latin American countries in 2013.

In Insert 7 we present a Similarity Structure Analysis (SSA) of Jewish identification in eight EU countries in 2012. The analysis addresses twelve selected variables each of which is represented by a point on the map.

The location of and distances between the points on the map reflect the intensity of correlation and co-variation between the different variables. Two neighboring points refer to two concepts that are very similar judging from the co-variation of answers of respondents toward the same and toward other concepts; two distant points refer to concepts that are less mutually related in the mind of the public. The whole space can be partitioned according to broader categories of contents providing the underlying meaning of the whole identification configuration. It should be stressed that SSA does not deal with frequencies of answers, only with similarity or dissimilarity of answers to different questions.

Questions concerning Jewish identification in Europe were formulated in terms of the degree of importance attributed by a respondent to a given indicator as an essential part of his/her own Jewish identity. The different indicators are 


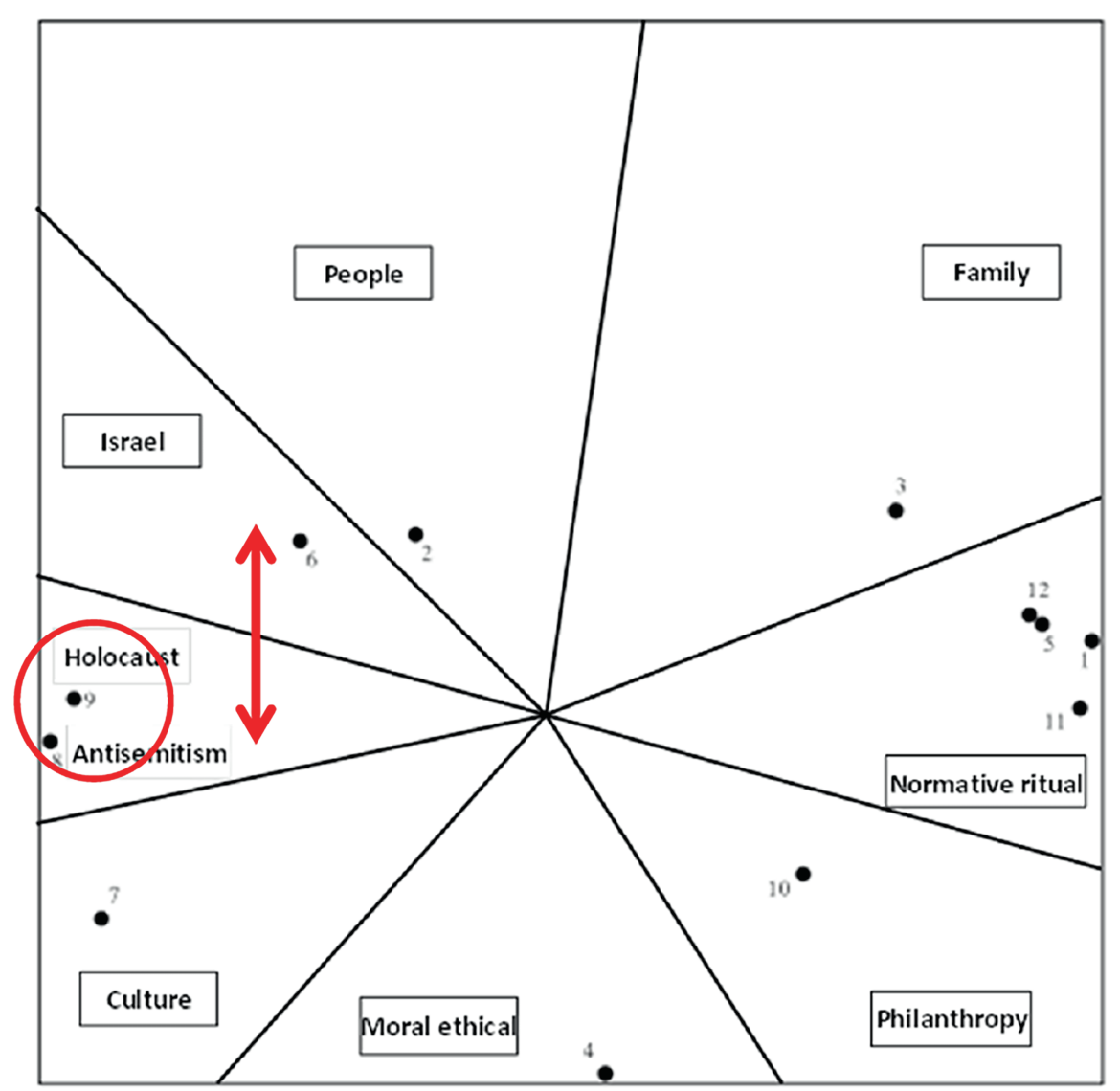

Image 7: Similarity Structure Analysis (SSA) of Jewish Identification in 8 EU Countries, 2012. Source: 2012 FRA Survey of Perceptions of Antisemitism among Jews in 8 EU countries. $\mathrm{N}=$ 5919. Author's processing.

related by mutual correlations that produce a circular configuration partitioned into conceptual domains. Beginning with the upper right quadrant, we recognize indicators of Jewish family and lifecycle, followed clockwise by several indicators of Jewish religious beliefs, norms, and rituals; Jewish philanthropy and community voluntarism; Jewish moral and ethical values; Jewish culture and education; memory of the Holocaust and fight against antisemitism-possibly to be construed as a domain of Jewish historical-political consciousness; feelings of solidarity toward the State of Israel; and belonging to Jewish peoplehood. Proximity of different domains points to some greater reciprocal affinity than to other domains in the configuration. We note in particular and underline the proximity 
that emerges between the Shoah/antisemitism sector and the Israel sector among Jews in the EU.

A similar procedure is followed in Insert 8 regarding Jews in the United States, based on the 2013 Pew Survey of Jewish Americans. ${ }^{30}$ The range of Jewish identification questions here is slightly different as there are nine of them, but the emerging map of contents in nearly identical to that seen for Europe. We detect the same circular configuration of variables and partition into conceptual domains, starting again with the Jewish family and moving clockwise to ritual normative indicators, philanthropy (a proxy for Jewish community), ethical values, Israel, the Holocaust, and belonging to Jewish peoplehood. Here too we can underline that the Holocaust and Israel identification dimensions pertain to neighboring domains. Salience of Holocaust in own Jewish identification is also relatively close to a general sense of belonging to the Jewish people. The similarity between the US and EU maps is in fact quite striking in view of several important differences that prevail in the general organization of society in the respective countries, and in the different modes of Jewish community organization-much more centralized in Europe and more disperse and voluntarist in the US.

A third observation of the structure of Jewish identification is presented in Insert 9 concerning a cross-section of the Jewish population from Latin America. As noted above, this is a more selective sample composed exclusively of educators mainly from Mexico and Argentina and spread today over five continents besides those still in the countries of origin. The number of Jewish identity indicators in this case is significantly higher and reaches 40 variables. Six of these, indicated by bright markers, refer to the Jewish communities of orientation of the respondents.

The partitions are substantially similar to those already seen, again beginning with Jewish family and moving clockwise to normative ritual, Jewish community (inclusive of philanthropy), civic participation in the non-Jewish public space, Jewish culture and history inclusive of memory of the Shoah and fight against antisemitism, and solidarity with Israel. A significant difference versus the EU and US configurations is the centrality of the Jewish peoplehood identification domain. Such a central point of shared focus and possibly mediation between other more distinct and consolidated identity options and persuasions also frequently appears in other studies of Jewish identification internationally

30 Cf. "A portrait of Jewish Americans,” Pew Research Center. 


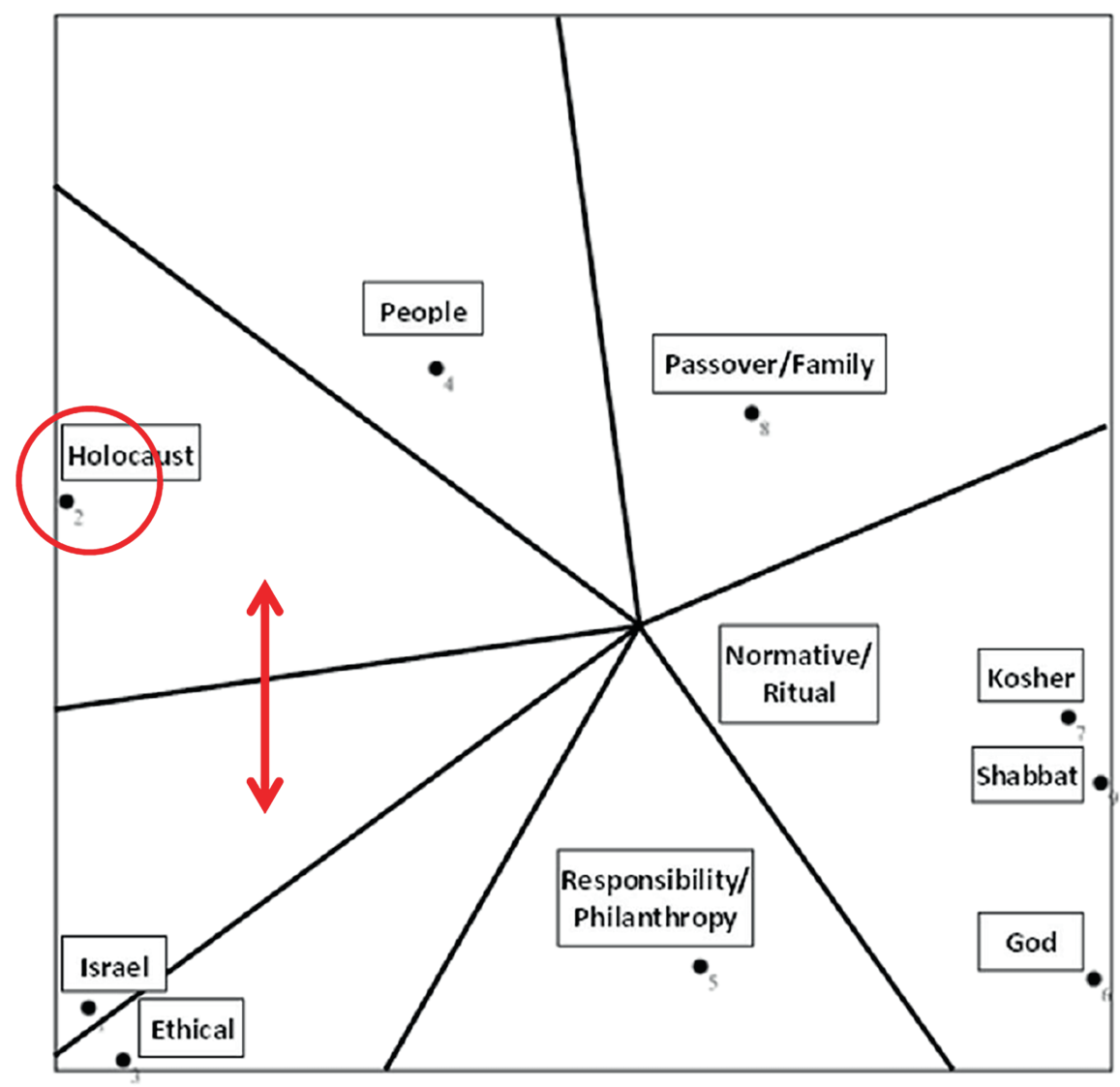

Image 8: Similarity Structure Analysis (SSA) of Jewish Identification in the United States, 2013. Source: 2013 Pew Survey of Perceptions of Jewish Americans. $N=3126$. Author's processing.

and in Israel. ${ }^{31}$ Among Latin American educators, once more, the identification domains of Holocaust and Israel are contiguous. ${ }^{32}$

31 Cf. S. Levy, "Jewish Identity Values of Israeli Youth and Adults in Contemporary Israel," in Research in Jewish Demography and Identity, ed. E. Lederhendler and U. Rebhun (Boston: Academic Studies Press, 2015), 288-305; S. DellaPergola et al., "The Structure of Jewish Identification in the United States: 2001 Revisited," in Jewish Population and Identity: Concept and Reality, ed. S. DellaPergola and U. Rebhun (Dordrecht: Springer, 2018), 43-71.

32 Cf. Bokser Liwerant et al., El educador judio latinoamericano. Processing by the author of this article. 


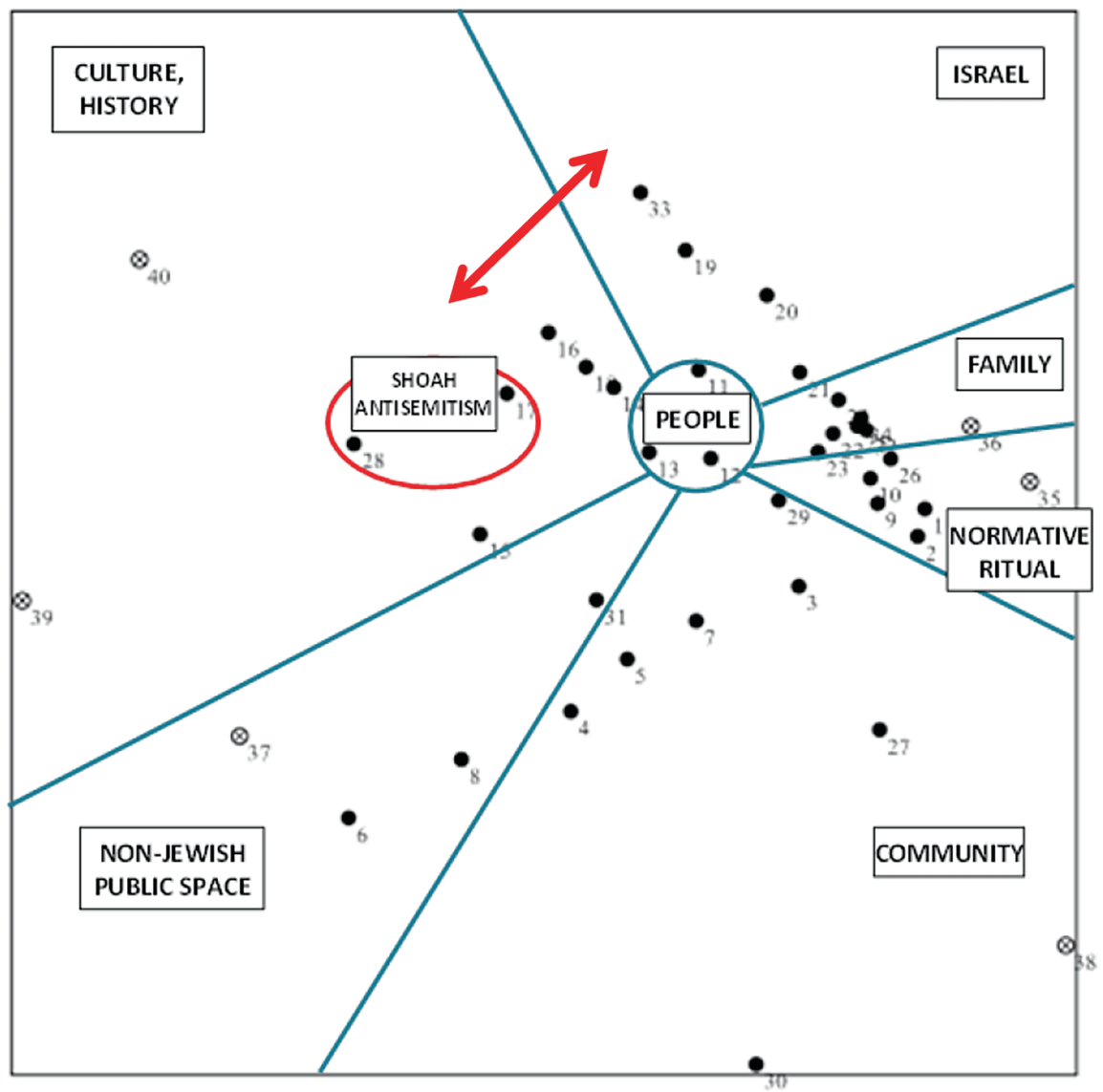

Image 9: Similarity Structure Analysis (SSA) of Jewish Identification among Latin American Jewish Educators, 2013. Source of data: 2013 Survey of Latin American Transnational Jewish Educators. $\mathrm{N}=1379$. Author's processing.

From these comparative analyses we evince two important conclusions. The first is that stable and repetitive patterns of Jewish identification prevail across the Jewish diaspora in very different cultural and geo-political contexts. Keeping in mind that in many cases contemporary Jewish communities are the product of international migration streams that started from similar countries of origin and split along the way, and in spite of long term separation and of the differences between countries of destination, it seems that important common threads still exist. Such perceptional commonalities involve in particular those sensitivities that are related to antisemitism. Antisemitism is perceived by Jews under different skies as something strictly correlated to the Shoah, and both are much more 
cognate with the Israeli aspect than with other aspects of their Jewish identification. The second implication of these similar sensitivities is a globalization of stimuli and reactions. Some antisemitic episode that occurs in one spot on earth is understood in exactly the same way by large numbers of Jews that are not locals but live elsewhere. Moreover, attacks on Israel resonate very closely with memory of the Shoah, and respectively delegitimation of Shoah is perceived by very many Jews as impacting on the safety of the State of Israel. We return to this point in the conclusions.

\section{Perceptions and Experiences of Antisemitism}

Moving from some of these somewhat theoretical premises to the more concrete reality of antisemitism, the 2012 FRA Survey collected data and analyzed a significant number of possible occurrences of antisemitism as perceived by a large sample of Jews in eight EU countries. In Insert 10 we present the frequencies reported with regard to 13 different indicators related to antisemitism. We indicate the average frequency for the total sample, the lowest and highest frequencies reported across the different countries, and in some cases the lowest and highest frequencies expressed toward a battery of options regarding the same issue among total Jewish respondents.

In Insert 10 the highest frequency is reported for a perception that antisemitism increased during the five years that preceded the survey, 2007-2012. Over three quarters (76\%) of the EU Jews' sample reported such an opinion. However this ranged between a low of $39 \%$ in Latvia and a high of $88 \%$ in France. Two other indicators elicited highly diffused perceptions by a majority of European Jews: the sense that antisemitism is a big problem in the country $-66 \%$ of the total sample, ranging between $44 \%$ in Latvia and $85 \%$ in France, and that the Israeli-Arab conflict impacts their own security-68\%, between $39 \%$ in Latvia and $93 \%$ in Belgium.

Other types of experiences rank at a significantly lower frequency level, such as worrying about becoming the victim of physical attack over the next 12 months (33\% of total respondents), witnessing verbal insult and/or physical attack during the last 12 months (27\%), or experiencing verbal insult and/or physical attack during the last 12 months (21\%). Still a lower layer of antisemitic experiences includes having suffered physical violence over the last 5 years $(7 \%)$, and having suffered physical violence over the last 12 months (4\%). Another type of perception relates to the propensity of respondents to identify a given statement as antisemitic. Out of a list of 14 statements (see below), respondents who recognized them as antisemitic ranged between $17 \%$ (Jews as only a reli- 


\begin{tabular}{|c|c|c|c|}
\hline Type of issue & Total & Low & High \\
\hline Perceives increase in antisemitism, last five years ${ }^{\circ}$ & 76 & 39 & 88 \\
\hline Feels Israel-Arab conflict impacts own security ${ }^{\circ}$ & 68 & 39 & 93 \\
\hline Antisemitism a big problem in country ${ }^{\circ}$ & 66 & 44 & 85 \\
\hline Identifies given statement as antisemitic ${ }^{\circ}$ & $=$ & 17 & 80 \\
\hline Context/transmission of antisemitic comment ${ }^{\circ}$ & $=$ & 14 & 75 \\
\hline Worries being victim of physical attack, nxt. 12 mo." & 33 & 17 & 60 \\
\hline Frequently heard listed antisemitic statement ${ }^{\circ}$ & $=$ & 11 & 48 \\
\hline Witnessed verbal insult/physical attack, 12 months ${ }^{\circ}$ & 27 & 17 & 43 \\
\hline Experienced verbal insult/physical attack, 12 mo." & 21 & 14 & 30 \\
\hline Suffered physical violence, last 5 years ${ }^{\circ}$ & 7 & 3 & 10 \\
\hline Suffered physical violence, last 12 months ${ }^{\circ}$ & 4 & 3 & 7 \\
\hline Felt discriminated in a social situation ${ }^{\circ}$ & $=$ & 1 & 11 \\
\hline Felt discriminated in a public service ${ }^{D}$ & $=$ & 2 & 8 \\
\hline
\end{tabular}

Image 10: Jewish Perceptions and Experiences of Antisemitism in 8 EU Countries, 2012 - Percentages.

a. Gaps assessed by country

b. Gaps assessed by listed modality

Source: FRA, Discrimination and Hate Crime, 2013, cit.

gious group and not a nation) and $80 \%$ (the Holocaust a myth or exaggerated), while those who actually heard those statements ranged between $11 \%$ (Jews not capable of integrating in society) and $48 \%$ (Israelis "Nazis"). The contexts or modes of transmission of antisemitic statements also widely ranged between $14 \%$ at sporting events and $75 \%$ on the internet. Finally, lower proportions of respondents felt discriminated in different social situations-between 1\% (in a bank or insurance company) and $11 \%$ (at the work place), or in public services-between 2\% (a local doctor) and $8 \%$ (the police).

One important emerging conclusion is that because of the multiform possible occurrences of antisemitic opinions and acts, from the attitudinal to the behavioral, frequencies of the respective experiences can variate greatly. We find three distinct levels of perception: one, mainly cognitive, shared by the vast majority of the Jewish public, refers to the general thrust and increase of antisemitism in society; a second more behavioral perception concerns 20 to $40 \%$ of the Jewish population who fear or actually witnessed verbal or physical violence; and a third, also behavioral, reported by less than $10 \%$ of respondents refers to actual violence suffered and to actual discrimination suffered in public 
offices. It is important to keep these differences in mind if one wishes to elaborate a measure capable of describing synthetically the incidence of antisemitism. ${ }^{33}$ The wide range of observable incidences precludes the feasibility of a single synthetic measure. Hence, much subjective latitude remains when, in order to characterize a certain situation, some observers may choose to refer primarily to indicators of antisemitism characterized by low frequency, while others may prefer to stress indicators characterized by high frequency (on the gradual perception and elasticity of antisemitism). ${ }^{34}$ Both are true, but their overall meaning should be deepened analytically by understanding the mutual relationships that exist between different types of antisemitic manifestations, beyond listing them in decreasing frequency order.

Insert 11 presents a Similarity Structure Analysis (SSA) of 14 different negative statements that were submitted to the eight country FRA respondents in order to verify whether they judge them to be antisemitic.

Reminding the serial lists of negative items already mentioned above, when mutually related the ones to the others the various concepts reveal their overall underlying logic. We observe again a circular configuration that can be partitioned into conceptual domains. Starting with the upper right quadrant and in clockwise progression, we detect a racist component (would not marry Jews, Jews are physically recognizable, or notable), an anti-Israeli component (criticize or boycott Israel, Jews are a religion not a nation hence not eligible to have a state of their own, Israelis Nazis), a Holocaust component (Holocaust a myth, Holocaust victimization exploitative), a classic Protocols of the Elders of Zion component (Jews hold excessive power, are responsible for economic crisis), and a foreignness component (Jews hold different interests from the rest of population, not integrated in society, not country nationals). Once more, the proximity between Holocaust and Israel dimensions emerges clearly in this analysis.

It is notable that in this map proximity relates to negative anti-Jewish images and prejudices, while in preceding analyses we noted such proximity in terms of the positive valence of Jewish identification. But the conclusions and implications are quite the same: Holocaust and Israel are once again proximate. The perceptional proximity of Holocaust variables and classic antisemitism variables is of interest too.

We can also infer that the variables in the upper part of the map include topics and themes that are shared with virtually all forms of racism and xenopho-

33 Cf. Popper et al., "Evaluating Contemporary Antisemitism."

34 Cf. D. Staetsky, “Quantifying Antisemitic Attitudes in Britain: The 'Elastic' View of Antisemitism,” issued October 2, 2017, accessed January 19, 2021, http://blogs.lse.ac.uk/polit icsandpolicy/the-elastic-view-of-antisemitism/. 


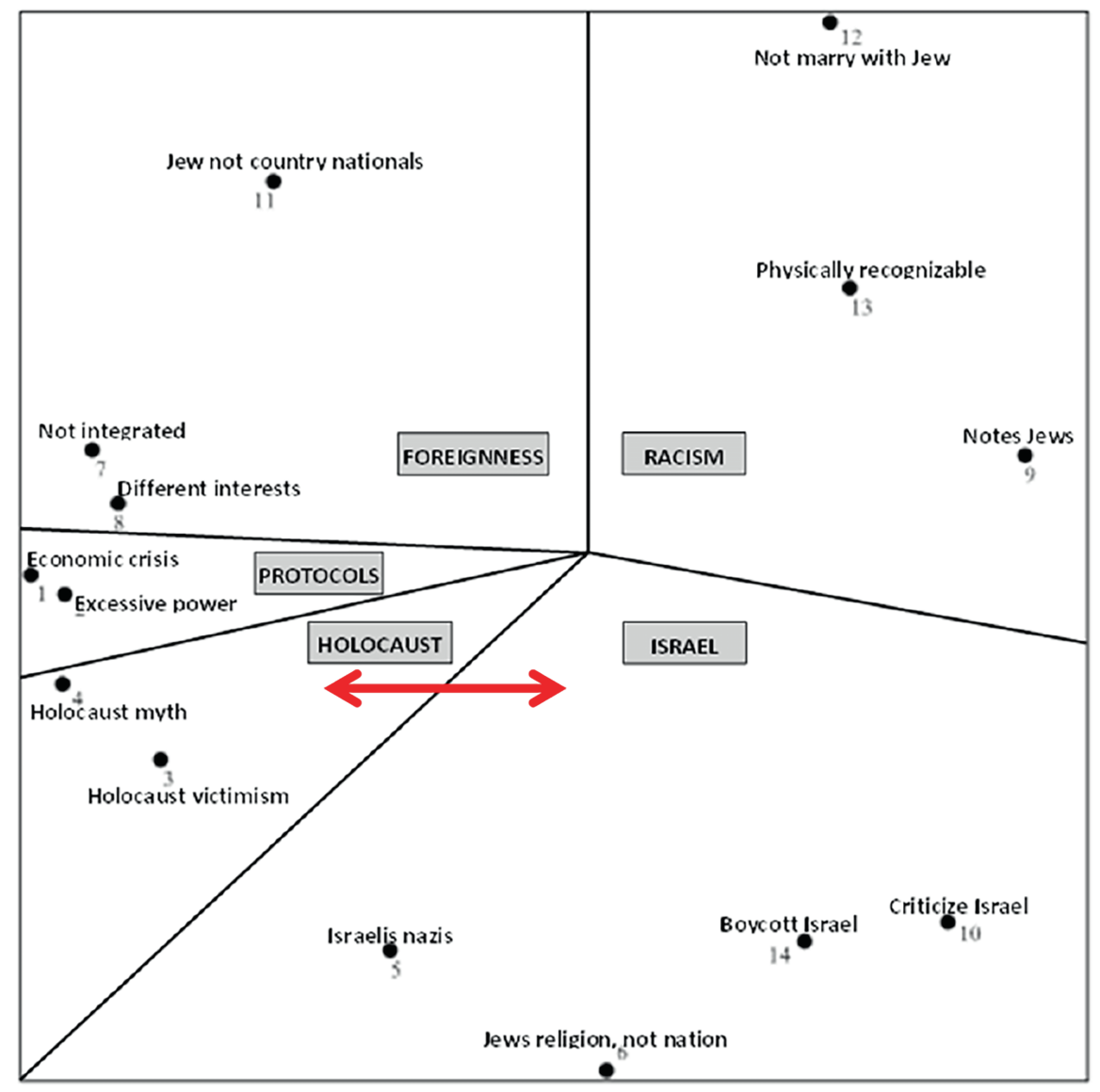

Image 11: Similarity Structure Analysis (SSA) of Cognitive Antisemitic Concepts as Perceived by Jews in 8 EU Countries, 2012. Source: 2012 FRA Survey of Perceptions of Antisemitism among Jews in $8 \mathrm{EU}$ countries. $\mathrm{N}=5919$. Author's processing.

bia, while in the bottom part of the map the themes are more directed at Jewish specificity. All variables reported in Insert 11 referred to cognitive aspects of antisemitism in a definitional sense.

Insert 12 addresses a more complex array of variables related to antisemitism perceptions and experiences including the fourteen preceding ones but adding many more, for a total of 56 variables some of which were reviewed in Insert 9. Here we start the reading of the map from the bottom right quadrant (Prejudice definition), which basically includes the same cognitive-definitional variables already seen in Insert 11. The next domain clockwise (Incidence assessment) includes variables dealing with subjective judgement about the frequency and 
mode of expression of different manifestations of antisemitism in the country of residence. The next sector (Incidents worry) relates to a respondent's fear that incidents might occur to him/her or to their family members. It is something that might happen but has not yet happened, and therefore still not yet in the behavioral/experiential domain. The contiguous domain (Prejudice heard) refers to the same definitions already reviewed in the Prejudice definition domain, but these have been perceived in the respondents' actual experience and therefore pertain to behavior rather than to cognition. The next domain (Discrimination experience) refers to actual experiences of discrimination suffered by self or family in the public space.

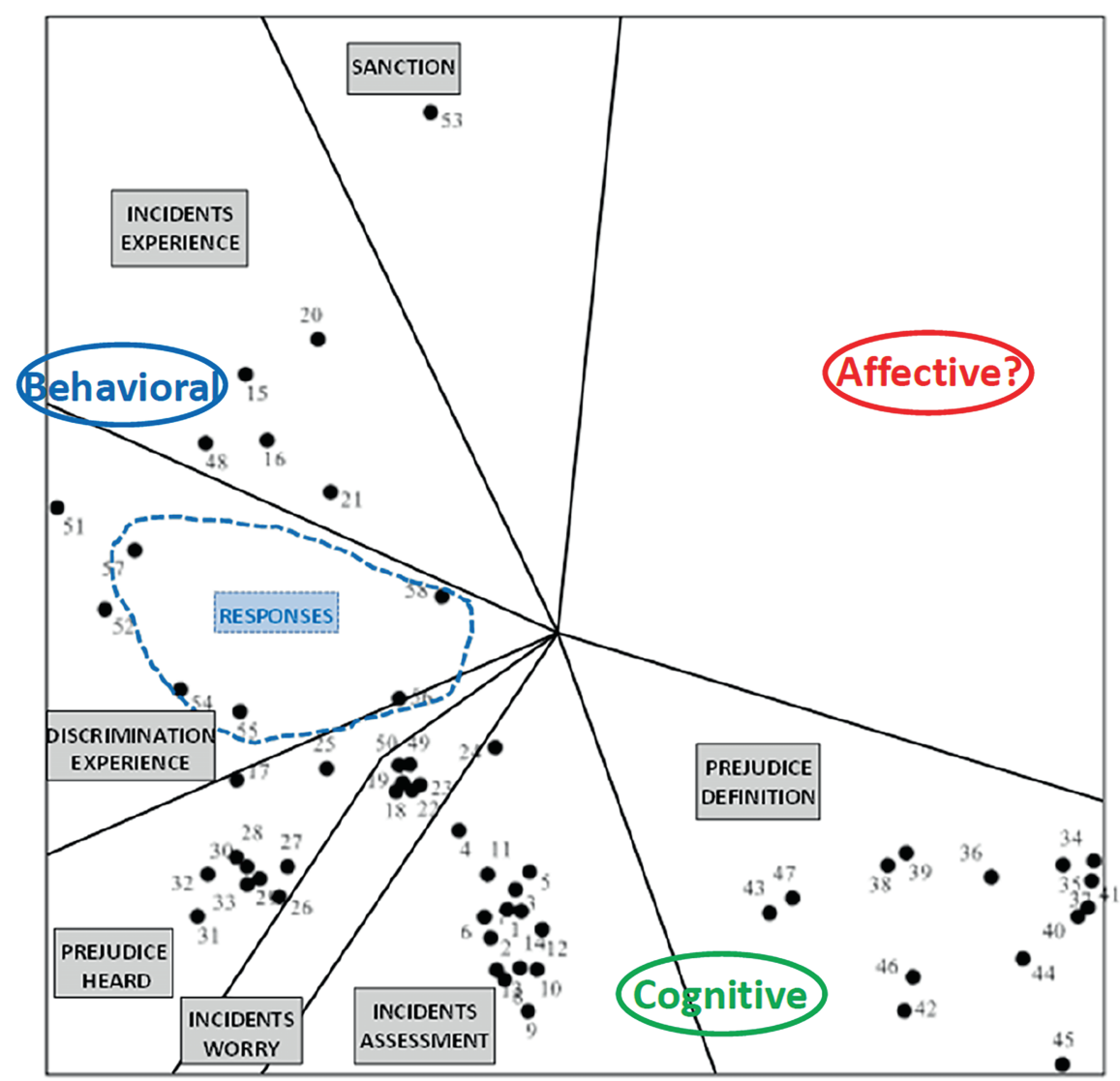

Image 12: Similarity Structure Analysis (SSA) of Antisemitism Perceptions and Experiences among Jews in 8 EU Countries, 2012. Source: 2012 FRA Survey of Perceptions of Antisemitism among Jews in $8 \mathrm{EU}$ countries. $\mathrm{N}=5919$. Author's processing. 
Interestingly, when one adds to the map the responses to antisemitism devised by respondents (such as emigration or deleting signs of ethno-religious identification), the respective variables fall into this same domain. This underlines the domain's behavioral character, although to a large extent such responses have not been translated into actual practice. The next domain (Incidents experience) refers to actual suffering of verbal or physical attack by respondent. Finally, the next domain (Sanction) refers to the respondent reaction in case local state legislation would forbid circumcision or ritual slaughtering of animals. The subject matter, if put into practice, would include a behavioral component, but the issue-as it was in 2012-was only theoretical. At the same time, the Jewish public was highly involved emotionally with the ongoing polemics on these issues.

This brings us to the next domain. There is a visible empty space in the upper right quadrant, and this represents what I shall call investigator's nightmare. In fact, the SSA theory and technique posits that if there is a conceptual space to be investigated and meaningfully partitioned into relevant domains, all of that space should be covered, the way of entry being appropriate questions posed to respondents. If there is a conspicuous empty space in a map, it means that the pertinent questions were not asked. What would those omitted questions be? Returning to the initial logical scheme presented above in Insert 1, we submit that the missing questions pertain to the affective domain. Questions of such nature, involving personal emotional reaction under the impact of antisemitism, were not asked indeed in the FRA study nor generally are in social scientific surveys. Our proposition cannot be demonstrated with absolute certitude, but it is worth considering in future studies.

One remarkable feature of Insert 11 is that when similar issues were investigated under two different angles-the cognitive and the behavioral-they appear as clearly separated clusters in the map and not regrouped by conceptual similarity (such as Holocaust or Israel). This further strengthens the assumption about the basic nature of the different domains that emerge from this analysis.

An additional word should be said about the channels of transmission through which antisemitism is spread. As noted above, the web and the new social media are an infinite and nearly unexplored sea of hostile but also of ambiguous content. We do not know how to exactly assess the real impact of incidents through the web. Sometimes something with a positive goal may have negative side effects and vice versa. I mention for example articles and appeals critically addressing the Israeli internal political debate, which have a positive moral and educational aim in mind but can be exploited by hostile people and organizations. There also are, in this respect, important grey zones whose contents can be interpreted on each side of the antisemitic divide. A better un- 
derstanding of these issues requires careful content analysis of the respective texts and expressions.

Summing up, regarding a typology of the contents of offence, our analysis confirms the assumption that three major strands dominate the current scene: Jewish excessive power, Holocaust denial, and Israel delegitimation. A fourth type stresses the foreignness of Jews, both physically and in relation to the local national context. A further type stressing the Jew as a physical and moral degenerate was important historically but is less central today. A new type recently emerged in the form of preoccupation toward the preservation of human or animal physical integrity-apparently neutrally humanistic-actually oriented against Jewish rituals such as circumcision or ritual animal slaughtering. This calls for reconsidering the ideological matrices of antisemitism. As to the tri-lateral typology of cognitive, behavioral, and affective domains, it seems that a more systematic exploration may bring essential missing notions to the study of antisemitism.

\section{Ideological Matrices of Antisemitism and Inner-Outer Perceptional Consistency}

Antisemitic offence may come from a broad spectrum of ideological matrices. Some rely on religious or otherwise transcendent premises-such as Pagan/Animist, Christian, or Muslim. Some derive from political ideas, such as right wing in its various manifestations (nationalist, fascist, Nazi), left wing in its various manifestations (Marxist, anarchist), or liberal-centrist. Christian (Catholic, Protestant, Orthodox) and Muslim (Sunni, Shia) antisemitisms-taking into account their internal variations-view the Jew as an unfaithful deviant, an enemy, but also as a potential neophyte, hence someone to be suppressed, curbed, dominated, or possibly converted to the ranks of the faithful. Left and Right political antisemitisms, each with their own particular and different emphases, identify among Jews negative characteristics-often specular and symmetric the ones to the others, such as at the same time the Jew as Capitalist and the Jew as Bolshevik, the Jew as reactionary and the Jew as revolutionary. For liberals, partly in the vein of early Pagans, one main quest is assimilation of the Jews into the cultural mainstream. A hostile perception of Jews as an ancient culture, separated and distinct from the majority, stands in conflict with the secular elites' quest to assimilate everybody into the norm - their norm. In this sense, Tacitus-a distinguished member of first-century pre-Christian elite-and Benedetto Croce-a leading twentieth-century Italian liberal philosopher-suggest nearly identical 
assimilationist propositions on Jews that we may not define antisemitism in today's terms, ${ }^{35}$ but they can easily be represented and exploited in contemporary antisemitic discourse. In contemporary political discourse, environmentalist/animalist political groups are leading in the effort to preserve the earth's natural status from human intervention, including on its living components. Therefore, among other things, they stigmatize and sanction traditional Jewish norms and behaviors that relate to circumcision and animal slaughtering. Consciously or not, these concepts were derived and metabolized from an ancient Christian ideational root. In the end, the shared offence of these different ideological matrices is that none recognizes the right of a Jew to be him or herself on Jewish terms of reference.

In the 2012 FRA study of Jewish perceptions of antisemitism, one aspect concerned the possible linkage of events in the Middle East and alleged Israel's responsibility in those events, with hostility against the local Jewish community. The findings are illustrated in Insert 13 where such association is analyzed at the country level according to four prevailing ideological matrices (Right, Left, Christian, Muslim) by which the perpetrators were identified by the Jewish public.

In most European countries examined, people associated with the Left were identified as more dominant in linking anti-Israeli attitudes to hostility against the local Jewish community, followed by people associated with Islam, andat some distance-by followers of the Right. The association with Christianity was quite lower, except for Hungary. There appeared to be an emerging coalescence between liberals and Islamists who could find common ground on some matters mostly related to antagonism against Israel. Different ideological matrices resulted in very different levels of statistical explanation of inter-country variation: $86.5 \%$ of explained variance across $8 \mathrm{EU}$ countries when the offence came from the Left; $69.7 \%$ when it came from Muslim extremists; 9.1\% when it came from the Right; and $0.2 \%$ when it came from Christian extremists. In other words, in the perception of Jews, the greater coherence across EU countries was found when problematic and dangerous statements linking together Israel and diaspora Jews came from the Left.

Another broader question is whether a group's internal perceptions of antisemitism are coherent with antisemitic perceptions and attitudes among the majority of society in the same countries. As noted above, the FRA 2012 study

35 Cf. S. DellaPergola and L. D. Staetsky, From Old and New Directions: Perceptions and Experiences of Antisemitism among Jews in Italy (London: JPR Jewish Policy Research Institute, 2015), http://archive.jpr.org.uk/download?id=1531. 


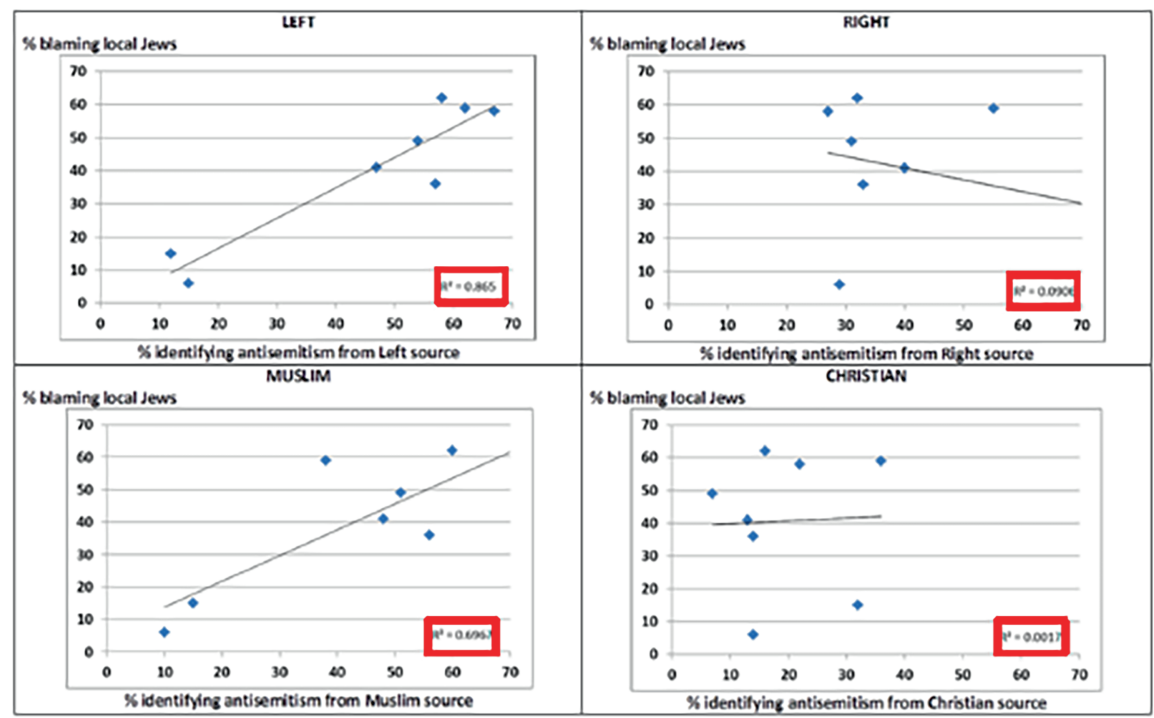

Image 13: Relationships between Main Ideological Matrices and Blaming Local Jews for the Middle East Conflict in 8 EU Countries, 2012. Source: 2012 FRA Survey of Perceptions of Antisemitism among Jews in $8 \mathrm{EU}$ countries. $\mathrm{N}=5919$. Author's processing.

measured perceptions by Jews while the ADL 2013-2014 study measured perceptions mostly by non-Jews. In both studies, the quality of the samples was not equal in different countries. But the capital question is whether the two surveys produced results that could be compared. In Insert 14 we compare the FRA and ADL findings for the $8 \mathrm{EU}$ countries that appear in both surveys.

The consistency of findings is very high, in the sense that generally higher perceptions with one type of indicator correspond to higher perceptions with the other type. General antisemitic perceptions in a given European country statistically explain over $54 \%$ of the variation in Jewish antisemitic perceptions in the same country. Hungary and France lead the pack on both accounts-though for different reasons: Hungary right wing and Christian, France left wing and Islamic. The UK was lowest on both accounts. This means that Jewish internal perceptions of antisemitism very much reflect ongoing antisemitic perceptions among the majority of society. We learn here an important lesson for future data collection: using one instrument instead of another, we may nevertheless obtain a robust indication of variation across countries of the antisemitic phenomenology. However, it should also be noted that Jewish (defensive) perceptions are significantly higher percentwise than general (offensive) perceptions. This confirms the assumption already largely documented above that sensitivity 
to antisemitism constitutes one of the essential components in the overall package of Jewish identification.

\section{$\%$ of Jews feeling antisemitism is a serious problem}

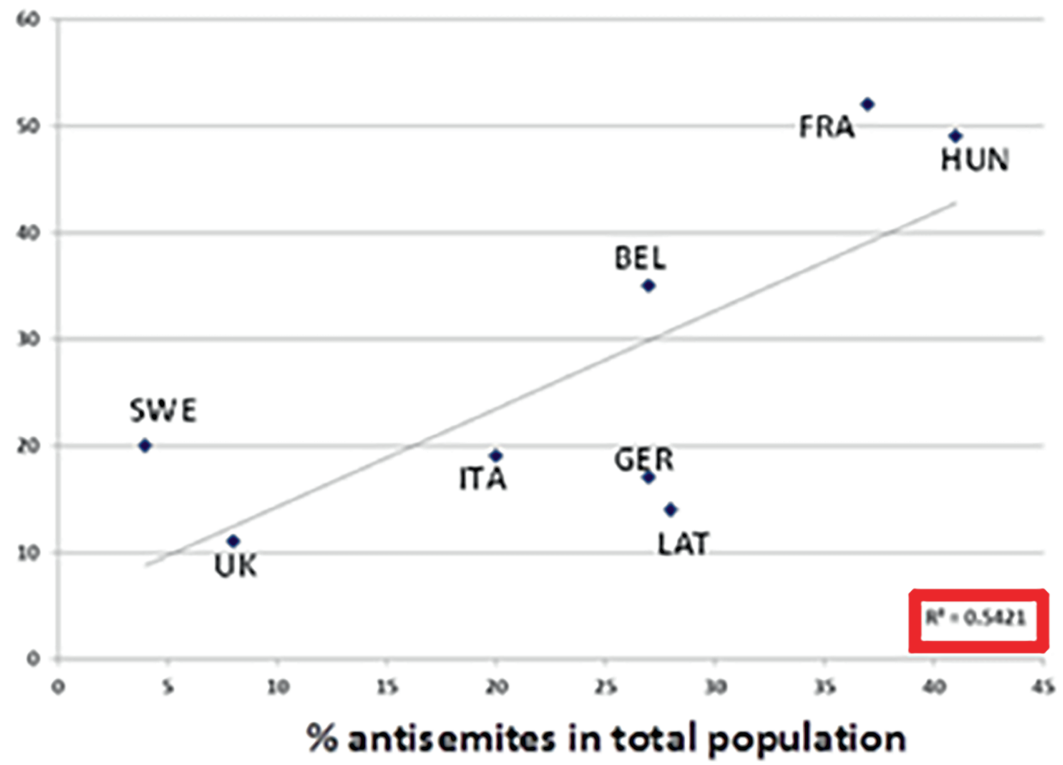

Image 14: Comparing Measures of Antisemitism in 8 EU Countries, 2012 vs. ADL 2013-14. Sources: 2012 FRA Survey of Perceptions of Antisemitism among Jews in 8 EU countries. $N=$ 5919; ADL (2014). Author's processing.

\section{Responses to Antisemitism}

A further question seldom investigated is what type of reaction antisemitism causes among the victims. Elaborating on this last observation, we look the frequency and patterns of Jewish response to instances of antisemitism. We would like to know more about who pursues counteracting action after the initial antisemitic event; toward what individual or authority; what the sanction applied is, if any; and what its effectiveness is. What surely is prominently missing in the available knowledge about antisemitism is an accurate assessment of the interrelations between one and another of these different dimensions.

Insert 15 provides a selection of possible responses and the inter-country variation of their frequencies. First, awareness is fairly high among Jews of the legal and political instruments that may be available in different EU countries 
to protect Jews from antisemitic offense. Overall a majority are aware of laws against anti-Jewish hatred (74\%), against discrimination (57\%), and against denial of Holocaust (54\%). However the inter-country variation is extremely broad with extremely low levels in some cases. Jewish response is much lower regarding possible personal behavioral changes than might reduce the impact of antisemitism, such as avoiding of wearing Jewish identifying signs (20\%, ranging between $5 \%$ and $34 \%$ across countries) or emigrating from the country (29\%, ranging between $18 \%$ and $48 \%$-see more below). Even lower are the propensities to report and denounce serious antisemitic incidents to the authorities $(18 \%$, ranging between $4 \%$ in Sweden and $24 \%$ in the UK). This suggests much Jewish diffidence or even resignation in front of the extant situation.

\begin{tabular}{lccc}
\hline Type of response & Total & Low & High \\
\hline Aware of law that forbids hatred against Jews & 74 & 14 & 84 \\
\hline Aware of law that forbids discrimination & 57 & 12 & 73 \\
Aware of law that forbids denial of Holocaust & 54 & 2 & 85 \\
Considered emigrating from country & 29 & 18 & 48 \\
\hline Avoidance of wearing Jewish identifying signs & 20 & 5 & 34 \\
Reporting most serious incident to authority & 18 & 4 & 24 \\
\hline
\end{tabular}

Image 15: Responses to Antisemitic Perceptions and Experiences, 8 EU Countries 2012 ${ }^{\mathrm{a}}$ - Percentages. a. Gaps assessed by country. Source: FRA, Discrimination and hate crime, 2013, cit.

Regarding concrete Jewish responses to antisemitism, perhaps the most radical one would be emigration from the country of residence, and the question is whether or not this is occurring or likely to occur. In the FRA survey, 18\% of the Jewish population in France would consider moving from their neighborhoods on grounds of perceived insecurity to other more secure areas in France, and one half of these already did. Over $40 \%$ of the Jews in France also indicated that they would consider emigrating from the country. One test of those intentions is to look at actual patterns of Jewish emigration from France. Insert 16 shows the monthly variation of aliyah-emigration to Israel-from the world, from the Former Soviet Union (FSU), and from France between 2013 and 2018. It also points to the timing of major acts of terrorism in France, some of which were aimed at general targets and some at Jewish targets: in 2012 against a Jewish school in Toulouse, at the beginning of 2015 against the satiric magazine Charlie Hébdo and against a kosher mini-market, toward the end of 2015 against 
the Bataclan theatre and several other targets, and in July 2016 at the sea Promenade in Nice.

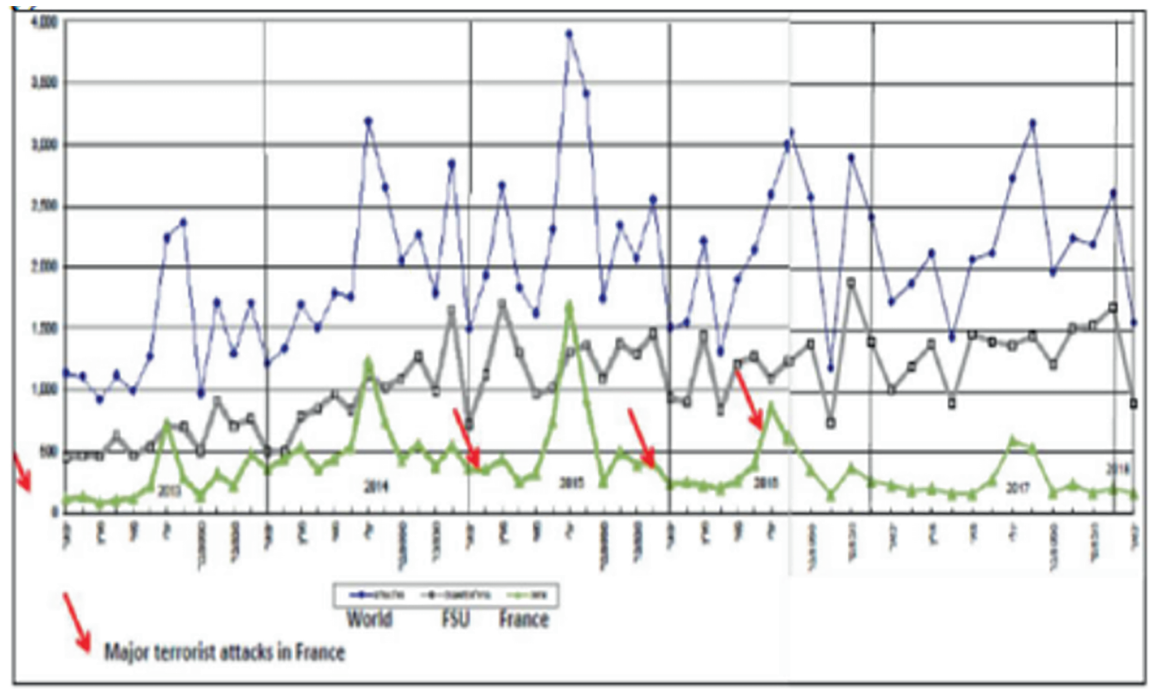

Image 16: Jewish Emigration from France to Israel in Response to Major Terrorist Attacks, Monthly, 2013-2018. Source: Israel Central Bureau of Statistics, Monthly Statistical Bulletin, monthly.

Evidently, Israel is only one of many possible countries of destination for Jews living in France and elsewhere, but it is the only one that provides orderly and detailed yearly data on the matter. ${ }^{36}$ Emigration from France clearly increased over time, especially in 2014 and 2015, possibly in relation to changing circumstances related to the fast increase in the Muslim minority, the increase in terrorist acts but also to some extent the evolving of general political discourse in France and the disparaging mingling of antisemitism within it. The exact timing of migration, however, did not have much to do with the time and intensity of terrorist attacks. Monthly variation, strongly concentrated in July and August, was rather related to the school year and to holidays. Several instances of major terrorist acts are indicated along the time axis, but monthly variation of aliyah continued to follow its independent rhythms. In 2016, 2017, and $2018 \mathrm{mi}$ gration from France clearly diminished versus 2014 and 2015, in spite of dramatic

36 Cf. "Statistical Abstract of Israel," Israel Central Bureau of Statistics, accessed January 19, 2021, https://www.cbs.gov.il/en/Pages/search/yearly.aspx. 
instances of continuing terrorism. Incidentally, immigration from the FSU is less seasonal because it is older and more dependent on Israel logistical and economic support. Further analyses of FRA and ADL data for many more countries unquestionably demonstrate that Jewish emigration is much more related to socioeconomic determinants-both personal and related to the level of economic development of the country of residence-than to levels of perceived antisemitism in a country. ${ }^{37}$

\section{Implications for Future Research and Concluding Remarks}

Our review of the national or transnational nature of antisemitism in light of contemporary research findings leads to several preliminary and some definitive conclusions. Some of these relate to method, others to substance. One thing, however, clearly emerges from our cumulated research findings: antisemitism is very largely perceived as a form of violence enacted against Jews. In fact-because of the complex manifest and latent interconnections that exist across different Jewish communities and between different aspects of the antisemitic morphology-antisemitism may come to be perceived as violence against the Jews. The vast majority of Jews-at least in the European Union-report perceptions of a significant increase of antisemitism in recent years, along with increases in racism and xenophobia. The vast majority report uneasiness or fear with the negative impact of the Israeli-Arab conflict on their own security.

Antisemitism has been and is a long-term resilient global feature, and contemporary globalization trends have strengthened its transnational character. The study of antisemitism at the local level is interesting and essentially informative, but a better analytic perspective is gained by expanding it to international comparisons and to globally integrated conclusions. Broadening the research perspective must involve not only the simultaneous observation of the antisemitic phenomenology over large and multicultural geographical territories and world regions but also the incorporation of many different and apparently unrelated aspects of the same phenomenology into one comprehensive and cogent analysis.

37 Cf. S. DellaPergola, "Jewish Demography in the European Union: Virtuous and Vicious Paths," in Being Jewish in 21st Century Central Europe, ed. H. Fireberg, O. Glöckner, and M. M. Zoufalá (Oldenbourg: De Gruyter, 2020), 17-56. 
Unlike in the past, most Jews today live in cultural areas characterized by low intensity of antisemitism, which also are better developed and the more democratic areas of the world. Therefore, the more relevant ground for observing antisemitism tends to become much less the local episode of discrimination or aggression, and much more the broader discourse on the fundamental themes at stake. Antisemitism thus affects symbolically and simultaneously all Jews as a global collective, beyond its past local salience. Antisemitism growingly becomes an insidious global transnational phenomenon unrelated to direct contact with Jews as real-life individuals but largely transmitted against Jews as an immanent collective. ${ }^{38}$ The resonance and impact of antisemitic discourse, and the exposure of Jews to it, is enormously magnified by ongoing globalization and growing transnationalism.

Research confirms what many would suppose at the level of personal intuition, namely that the main contemporary conceptual expressions of antisemitism include three main strands: attributing to the Jews economic-political power, dominance and exploitation, with further contentions of foreignness to the majority's national interests and physical recognizability; Shoah/Holocaust denial or manipulation; and Israel delegitimation and demonization. A fourth strand stressing the Jew as a physical and moral degenerate was important historically but is less central today, substituted by a Neo-Pagan mode of Jewish group targeted piety for the human body and animal integrity. Multiple ideological foundations of antisemitism did and do include Pagan, Christian, Muslim, left-wing, right-wing, and liberal-centrist components. Christians and Muslims view the Jew as enemy but also as possible neophyte. Political antisemitism condemns the Jew for different, specular and totally contradictory reasons. For liberals, the main theme was and remains assimilation of the Jews.

One also needs to look at the role of antisemitism as a component within the total space of Jewish identity and at the frequency and patterns of Jewish response. Contents wise, the cognitive/intellectual and behavioral/experiential domains of antisemitism have been sufficiently clarified. This is not the case with the affective/emotional domain and its relationships to other domains. Several

38 This is not a new phenomenon. Studies on pre-modern Judaism show that during these periods as much as in early modern and modern times, a population's attitude toward Jews was as much determined by external factors such as the image of Jews depicted in the Christian scriptures as it is today. Jeremy Cohen developed the concept of the "hermeneutical Jew" to describe this phenomenon. Cf. J. Cohen, Living Letters of the Law: Ideas of the Jew in Medieval Christianity (Berkeley: University of California Press, 1999), 10-19. Already in pre-modern times, it was not contact with a local Jewish community upon which antisemites based their constructions of Jewish identity but external factors that had nothing to do with actual Jewish life. 
studies in different continents reveal a strikingly similar configuration of the overall space of Jewish identification perceptions and feelings, and within it a particularly strong proximity relationship between the identification domain of memory of Shoah and fight against antisemitism, on the one hand, and the identification domain of Israel as a symbolic Jewish referent, on the other. The consequence is that attack against or denial of one domain may generate strong sensitivity among people who are attached to the other.

In this respect, thanks to the comprehensive conceptual insights allowed by the Similarity Structure Analysis approach, we came closer to decoding what perhaps is the fundamental crux of the Jewish perception of contemporary antisemitism. Comparative research identifies memory of the Shoah as the most frequent or one of the most frequently shared markers of Jewish identification. ${ }^{39}$ The evidence is also that denial or minimization of Shoah is the one discursive topic that Jews most frequently deem as offensively antisemitic. ${ }^{40}$ When discourse turns into criticism of Israel's government, or turns into denying or boycotting Israel's right to exist, because of the identificational proximity of Israel with the Holocaust, a highly sensitive chord is touched in the minds of many. In other words, the aggressive delegitimation mode evidently, but also the naive/neutral/factual Israel's government critique-which actually is peacefully accepted as legitimate by many Jews-tend to ignore the crucial latent connection that, rightly or wrongly, turns such arguments into harassment in the perception of the majority of contemporary Jews.

Another important finding was that the analysis of antisemitism cannot be disjoint from the different meaning and salience of its cognitive, behavioral, and affective domains. We found that within each of these different modes variables display a mutual relationship and internal order that greatly helps mapping the contents of the phenomenon. However, when the different domains are mapped together, the public tends to regroup separately the cognitive from the experiential and presumably from the affective (although the latter was not really studied).

These findings should be helpful when one wishes to reconsider the nature and priorities of future research. We have argued that still today most available research on antisemitisms relies on data collection and cataloguing of events

39 Cf. S. DellaPergola, “Jewish Peoplehood: Hard, Soft, and Interactive Markers," in Reconsidering Israel-Diaspora Relations, ed. E. Ben-Rafael, J. Bokser Liwerant, and Y. Gorny (Leiden: Brill, 2014), 25-59; “A portrait of Jewish Americans,” Pew Research Center; Bokser Liwerant et al., El educador judío latinoamericano.

40 Cf. FRA, Discrimination and Hate Crime. 
from the field and on cross-sectional surveys of a given population at one specific point of time. In fact the main data collection strategies have included:

- Inventories of antisemitic acts of violence/aggression/profanation/discrimination reported to Jewish communities or to the security authorities of the different countries;

- Cross-sectional surveys of the incidence of prejudice among a representative sample of the total population;

- Cross-sectional surveys of the extent of suffered/perceived violence/aggression/prejudice/ discrimination among a representative sample of the Jewish population.

Reflecting on our analysis, in future research repeated data collections based on similar instruments are needed to allow for robust comparisons over time. One important case in point is the FRA survey of experiences and perceptions of antisemitism in EU member states, which after the successful round in 2012 was replicated in 2018 in an expanded number of countries and with much improved rates of response. A better and deeper time perspective should also be introduced through retrospective questioning in cross-sectional surveys of own experiences and recollections at different points in the lifecycle (childhood, adulthood, and later); or much better, through longitudinal studies, namely the periodical re-interviewing of representative panels of respondents. This would allow monitoring and following up changes occurring among the Jewish and broader public opinion over time and would provide a more consistent and accurate impression of changing experiences, perceptions, and narratives. Such panels need to be renewed periodically and may produce unprecedentedly useful insights. They potentially provide a new mechanism apt to send a regular flow of information to those interested and may create an observatory about a field in permanent transformation.

No one can deny the fundamental importance of continuing the search for the number of antisemitic events, the number of perpetrators, the number of people exposed to the event-namely the multiplier of events and people exposed to them, and the perceptions of antisemitism by Jews and by non-Jews. In this paper, trying to answer an essentially qualitative question we represented several research approaches largely relying on quantitative data. The logic explicitly or latently followed was, on the one hand, that of statistical inference, and on the other hand, that of building more complex systemic models of the whole cognitive and behavioral space of those concerned. An attempt was pursued to bring together tens of different variables and analyze them simultaneously with the help of techniques (like SSA) that aim to unveil the fundamental structure of an issue even more than its frequency. This approach seems 
highly appropriate to help better understanding the latent sides of individual and collective human behaviors.

But additional updated and appropriate research methods should be applied to reach and unveil the multivariate depth and complexity of the overall phenomenology of violence and unequal treatment of otherness in society. We should develop and strengthen a real comparative framework, time- and place-wise, and associate it with external events such as economic and political conjuncture, while understanding differential geographic, demographic, socioeconomic, and cultural characteristics of perpetrators and victims alike.

We should have a better representation of the main channels of diffusion of antisemitism and of their efficiency. Among these the web tends to become the most polluted, overcoming the conventional printed and electronic media whose effects are more elusive but can reach far larger audiences. In order to decipher antisemitic discourse through the social and electronic media, we need a coherent mapping sentence capable of integrating its multivariate contents; a better outline of the active and passive actor; a better assessment of who pursues action after the initial antisemitic event; and a better notion of what the consequences of such reaction are. A systematic content analysis is needed of antisemitic discourse generated in politics, the media, cultural and artistic representation, and the academy-with particular attention to double standards toward Jews and Israel, and toward others through careful reading and recombining of words and word sequences, but also body languages and the respective contexts. We need more integrated and semantics-sensitive studies in which all that in the daily printed press, television and radio, internet, emails, social media is associated with Jews and/or with Holocaust and/or with Israel should be scrutinized, categorized, contextualized, and interpreted.

When assessing the reality of contemporary antisemitism, or any related topic, there is no pretention here to affirm the superiority of quantitative over qualitative research, or of one quantitative technique over another. Different disciplinary approaches in history, literature, and the social sciences, and the respective different methodologies are all legitimate and useful when tackling the issues, provided each is conducted systematically, within its own appropriate disciplinary paradigms and keeping in mind that there exist other disciplinary paradigms.

One important difference across disciplines is that some of them focus on the specific experiences of individual Jewish actors, while others focus on aggregate or collective Jewish communities, or on the non-Jewish societal environment at large. A micro-social research approach often infers the broader reality from the experiences of relatively small groups, such as intellectuals, writers and their work, and witnesses in general who can provide the lead to other broader 
realities. A macro-social approach assesses the picture based on the collective understandings, performances, and feelings of the largest possible number of anonymous informants, within which the elites are included but do not constitute the dominant factor. Each approach has its advantages and disadvantages, the main trade-off being between depth and representativeness.

A recurring research question is whether it would be useful to integrate every possible facet of antisemitism into one measure, or rather choose to develop multiple measures adjusted to multiple types of situations and contexts. ${ }^{41}$ Ways should be developed to coordinate research from different sources way beyond what was done so far. Comprehensive assessments are better reached based on multiple sources. One example provided here was the attempt to integrate the macro approach of the ADL world survey with the more micro approach of the FRA EU Jewish survey. Comparison of the same measures or complementing different measures across sources is imperative to a better understanding of antisemitism.

Most broadly stated the ultimate question is: How should one react to antisemitism? Can an end be put to antisemitism? Does one stop at the analytic edge, or should more operational initiatives be contemplated? The epistemic community of scientific researchers and public intellectuals should engage in analyzing, teaching, explaining, arguing, advocating, persuading, and combating. Academic books and articles in good general journals are an essential step in the dissemination of knowledge. Academic projects should be developed to gather incrementally better understanding of the phenomenology and also to create the necessary know-how premises that might help creating the foundations for policies aimed at fighting antisemitism. Continuing documentation and monitoring calls for with the involvement of Israeli, World Jewish, and general public institutions. A much stronger relationship should be established between research on antisemitism and research on all other forms of racism, xenophobia, discrimination, marginalization, and harassment in relation to other religious, ethnic, and linguistic groups, and in relation to communities who prefer lifestyles different from those of the majority. Who are those who should be concerned with old and new manifestations of antisemitism? Who should initiate the just mentioned kinds of response? Can or should worries, interests, and energies be organized and conveyed coherently? There already exist a number of roof organizations, like the IHRA, that work to promote a fair international educational platform to fight antisemitism, and they should be more intimately connected with the world of research.

41 Cf. Popper et al., "Evaluating Contemporary Antisemitism.” 
A reaction strategy against antisemitism should also include educating people to know and appreciate Jewish values and history, doing good deeds and providing good behavioral examples, being alert and politically active, bringing people to directly know, freely evaluate, and if necessary also civilly disagree with Jewish and Israeli realities. It also is essential to pursue alliances with the many persons and organizations of good will, from all strands, which in the last analysis constitute the majority of society. As a last resort-one should know how to develop adequate self-defense initiatives. These questions among others, and the answers they will receive, will determine the map, impact, and hopefully diminished visibility and viability of antisemitism in the twenty-first century. Because one thing is assured: there will be antisemitism in the twenty-first century.

\section{Acknowledgments}

Work for this paper was undertaken at the Division of Jewish Demography and Statistics of the A. Harman Institute of Contemporary Jewry of the Hebrew University of Jerusalem, headed by Uzi Rebhun. Preliminary results of this study were presented on several occasions: at the ISGAP expert consultation on measuring antisemitism, Paris, September 2016-thanks are due to Charles Small and Mala Tabori for their support; at the international conference An End to Antisemitism!, Vienna, February 2018; at the Global Forum on Antisemitism, Jerusalem, March 2018; at the International Sociological Association ISA World Conference, Research Committee 22, Sociology of Religion, Toronto, July 2018. Data collection and processing for this paper greatly benefitted from the 2012 FRA project coordinated at Jewish Policy Research Institute JPR in London by Jonathan Boyd and Daniel Staetsky. Special data processing of the Pew survey of Jewish Americans were obtained through the courtesy of Alan Cooperman and Neha Saghal at the Pew Research Center in Washington, DC, and processed by Ariela Keysar of Trinity College, Hartford, CT. The Latin American TNJE study-jointly undertaken with the Universidad Hebraica in Mexico City and AMIA in Buenos Aires, with the sponsorship of the Pincus Fund for Jewish Education in Jerusalem-was coordinated at the Liwerant Center for the Study of Latin America, Spain and Portugal and their Jewish Communities at the Hebrew University of Jerusalem by the author with Judit Liwerant, Leo Senkman, and Yosi Goldstein, while data were processed by Maya Shorer Kaplan. To all I express my sincere appreciation. Responsibility for the contents of this paper is the author's only. 
Sergio DellaPergola is Professor Emeritus and former Chairman of the Hebrew University's Avraham Harman Institute of Contemporary Jewry. A specialist on the demography of world Jewry, he published or edited 60 books and monographs including Jewish Demographic Policies: Population Trends and Options (2011) and over 300 papers on historical demography, the family, international migration, Jewish identification, antisemitism, and projections in the Diaspora and in Israel. DellaPergola has lectured at over 100 universities and research centers all over the world and was senior policy consultant to the President of Israel, the Israeli Government, the Jerusalem Municipality, and major national and international organizations.

\section{References}

Adorno, Theodor W., Else Frenkel-Brunswik, Daniel Levinson, and Nevitt Sanford. The Authoritarian Personality. New York: Harper, 1950.

Almog, Shmuel, ed. Antisemitism through the Ages. Oxford: Pergamon, 1988.

Amar, Reuven, and Shlomit Levy. "SSA-Similarity Structure Analysis." In Encyclopedia of Quality of Life and Wellbeing Research, edited by Alex C. Michalos, 6306-313. Dordrecht: Springer, 2014.

Anti-Defamation League. “ADL Global 100: An Index of Anti-semitism.” Issued 2014. Accessed January 2021. https://global100.adl.org/map.

Bauer, Yehuda, ed. Present-Day Antisemitism. Jerusalem: The Vidal Sassoon International Center for the Study of Antisemitism at the Hebrew University, 1988.

Bauer, Yehuda. Rethinking the Holocaust. New Haven: Yale University Press, 2002.

Beller, Steven. Antisemitism. A Very Short Introduction. New York: Oxford University Press, 2015.

Ben-Rafael, Eliezer. Confronting Allosemitism in Europe: The Case of Belgian Jews. Leiden: Brill, 2014.

Bokser Liwerant, Judit, Sergio DellaPergola, Leonardo Senkman, and Yossi Goldstein. El educador judío latinoamericano en un mundo transnacional. Vol. 1. Informe de investigación. Vol. 2. Sintesis, conclusiones y recomendaciones del informe de investigación. Jerusalem: The Hebrew University, Centro Liwerant para el estudio de America Latina, España, Portugal y suyas Comunidaded Judías; Mexico: Universidad Hebraica; Buenos Aires: AMIA, 2015.

Brown, Michael, ed. Approaches to Antisemitism: Context and Curriculum. New York: The American Jewish Committee and the International Center for University Teaching of Jewish Civilization, 1994.

Cohen, Jeremy J. Living Letters of the Law: Ideas of the Jew in Medieval Christianity. Berkeley: University of California Press, 1999.

DellaPergola, Sergio. "Jewish Demography in the European Union: Virtuous and Vicious Paths." In Being Jewish in 21st Century Central Europe, edited by Haim Fireberg, Olaf Glöckner, and Marcela Menachem Zoufalá, 17-56. Oldenbourg: De Gruyter, 2020. 
DellaPergola, Sergio. "Jewish Peoplehood: Hard, Soft, and Interactive Markers." In Reconsidering Israel-Diaspora Relations, edited by Eliezer Ben-Rafael, Judit Bokser Liwerant, and Yosef Gorny, 25-59. Leiden: Brill, 2014.

DellaPergola, Sergio. “World Jewish Population 2013." In American Jewish Year Book 113, edited by Arnold B. Dashefsky and Ira M. Sheskin, 278-358. Dordrecht: Springer, 2013.

DellaPergola, Sergio. "World Jewish Population 2017." In American Jewish Year Book 117, edited by Arnold B. Dashefsky and Ira M. Sheskin, 297-377. Dordrecht: Springer, 2017.

DellaPergola, Sergio, and L. Daniel Staetsky. From Old and New Directions: Perceptions and Experiences of Antisemitism among Jews in Italy. London: Jewish Policy Research Institute, 2015. http://archive.jpr.org.uk/download?id=1531.

DellaPergola, Sergio, Shlomit Levy, Uzi Rebhun, and Dalia Sagi. "The Structure of Jewish Identification in the United States: 2001 Revisited." In Jewish Population and Identity: Concept and Reality, edited by Sergio DellaPergola and Uzi Rebhun, 43-71. Dordrecht: Springer, 2018.

DellaPergola, Sergio, and Usiel Oskar Schmelz. "Demography." Encyclopedia Judaica, 2nd ed., 5:553-72. Farmington Hills: Thompson Gale, 2006.

Epstein, Simon. Cyclical Patterns in Antisemitism: The Dynamics of anti-Jewish Violence in Western Countries since the 1950s. Jerusalem: Vidal Sassoon International Center for the Study of Antisemitism at the Hebrew University, 1993.

Ettinger, Shmuel. Modern Anti-Semitism. Tel Aviv: Moreshet, 1978 [in Hebrew].

European Union Agency for Fundamental Rights (FRA). Antisemitism: Overview of Antisemitic Incidents Recorded in the European Union 2009-2019. Luxembourg: Publications Office of the European Union, 2020. https://fra.europa.eu/sites/default/files/fra_uploads/fra2020-antisemitism-overview-2009-2019_en.pdf.

European Union Agency for Fundamental Rights (FRA). Antisemitism: Overview of Data Available in the European Union 2008-2018. Luxembourg: Publications Office of the European Union, 2019. https://fra.europa.eu/sites/default/files/fra_uploads/fra-2019-an tisemitism-overview-2008-2018_en.pdf.

European Union Agency for Fundamental Rights (FRA). Discrimination and Hate Crime against Jews in EU Member States: Experiences and Perceptions of Antisemitism. Luxembourg: Publications Office of the European Union, 2014. http://fra.europa.eu/sites/default/files/ fra-2013-discrimination-hate-crime-against-jews-eu-member-states-0_en.pdf.

European Union Agency for Fundamental Rights (FRA). Experiences and Perceptions of Antisemitism: Second Survey on Discrimination and Hate Crime against Jews in the EU. Luxembourg: Publications Office of the European Union, 2018. https://fra.europa.eu/ sites/default/files/fra_uploads/fra-2018-experiences-and-perceptions-of-antisemitism-sur vey_en.pdf.

European Union Agency for Fundamental Rights (FRA). Young Jewish Europeans: Perceptions and Experiences of Antisemitism. Luxembourg: Publications Office of the European Union, 2019. https://fra.europa.eu/sites/default/files/fra_uploads/fra-2019-young-jewisheuropeans_en.pdf.

Glock, Charles Y., and Rodney Stark. Christian Beliefs and Anti-Semitism. New York: Harper Torchbooks, 1966.

Guttman, Louis. "A General Nonmetric Technique for Finding the Smallest Coordinate Space for a Configuration of Points." Psychometrika 33 (1968): 469-506. 
Inglehart, Ronald, and Christian Welzel. Modernization, Cultural Change and Democracy: The Human Development Sequence. Cambridge: Cambridge University Press, 2005.

International Holocaust Remembrance Alliance. "Working Definition of Antisemitism." Issued May 26, 2016. Accessed January 8, 2021. https://www.holocaustremembrance.com/ sites/default/files/press_release_document_antisemitism.pdf.

Israel Central Bureau of Statistics. "Statistical Abstract of Israel." Accessed January 19, 2021. https://www.cbs.gov.il/en/Pages/search/yearly.aspx.

Jewish Voice for Peace. On Antisemitism: Solidarity and the Struggle for Justice, with a preface by Judith Butler. Chicago: Haymarket Books, 2017.

Kantor Center for the Study of Contemporary European Jewry, ed. Antisemitism Worldwide 2017: General Analysis Draft. Tel Aviv: Moshe Kantor Database for the Study of Contemporary Antisemitism and Racism, 2018.

Knobel, Marc. Haïne et violences antisémites. Une rétrospective 2000-2013. Paris: Berg International, 2013.

Levy, Shlomit. "Jewish Identity Values of Israeli Youth and Adults in Contemporary Israel." In Research in Jewish Demography and Identity, edited by Eli Lederhendler and Uzi Rebhun, 288-305. Boston: Academic Studies Press, 2015.

Lewis, Bernard. Semites and Anti-Semites. New York: Norton, 1987.

Marcus, Kenneth L. The Definition of Anti-Semitism. New York: Oxford University Press, 2015. Organization for Security and Co-operation in Europe. Hate Crime Reporting. Anti-Semitism 2016. Vienna: Organization for Security and Co-operation in Europe, Office for Democratic Institutions and Human Rights, 2016. http://hatecrime.osce.org/what-hatecrime/anti-semitism.

Pew Research Center. "A Portrait of Jewish Americans: Findings from a Pew Research Center Survey of U.S. Jews." Issued October 1, 2013. Accessed January 19, 2021. https://www. pewforum.org/2013/10/01/jewish-american-beliefs-attitudes-culture-survey/.

Poliakov, Léon. The History of Anti-Semitism. 4 vols. Philadelphia: Philadelphia University Press, 2003.

Popper, Steven W., Dan Shalmon, Charles Asher Small, Mala Tabory, and Tal Wolfson. "Evaluating Contemporary Antisemitism: A Framework for Collaborative Conceptualization, Measurement and Assessment." Draft paper, Institute for the Study of Antisemitism and Policy. Last updated January 22, 2017. https://isgap.org/wp-content/up loads/2019/10/Measuring-Antisemitism.pdf.

Rebhun, Uzi. "Correlates of Experiences and Perceptions of anti-Semitism among Jews in the United States." Social Science Research 47 (2014): 44-60.

Schwarz-Friesel, Monika, and Jehuda Reinharz. Inside the Antisemitic Mind: The Language of Jew-Hatred in Contemporary Germany. Boston: University Press of New England, 2017.

Staetsky, Daniel. "Quantifying Antisemitic Attitudes in Britain: The 'Elastic' View of Antisemitism." Issued October 2, 2017. Accessed January 19, 2021. http://blogs.lse.ac. uk/politicsandpolicy/the-elastic-view-of-antisemitism/.

United Nations Development Programme. Human Development Report 2017. New York: United Nations Development Programme, 2017.

UN Watch. The United Nations and Antisemitism: 2008-2017 Report Card. New York: UN Watch, 2018.

Wieviorka, Michel. L'antisémitisme. Paris: Balland, 2005. 
Wistrich, Robert. A Lethal Obsession: Anti-Semitism from Antiquity to the Global Jihad. New York: Random House, 2010. 